\title{
Evocative gene-parenting correlations and academic performance at first grade: An exploratory study
}

\author{
CATHI B. PROPPER, MICHAEL J. SHANAHAN, ROSEMARY RUSSO, AND W. ROGER MILLS-KOONCE \\ University of North Carolina at Chapel Hill
}

\begin{abstract}
Academic performance during the first years of school lays the groundwork for subsequent trajectories of academic success throughout childhood and adolescence. The current study tests a model according to which a gene-parenting correlation in the first 3 years of life is associated with subsequent psychosocial adjustment and then academic performance in the first grade (as indicated by teachers' assessment of academic behavior and two subscales of the Woodcock-Johnson Test of Achievement, Third Edition). Drawing on multiple waves of data from the Durham Child Health and Development Study, we find that risk alleles for dopamine receptor genes (dopamine receptor D4 for girls, dopamine receptor D2 for boys) are associated with less sensitive parenting. For girls, parenting mediates the link between dopamine receptor D4 and all academic outcomes. There is some indication that parenting also influences girls' withdrawn behavior in the classroom, which in turn influences teachers' assessments of academic performance. For boys, some evidence suggests that parenting is associated with emotion regulation, which is associated with teachers' assessments of academic behavior and both subscales of the WoodcockJohnson. Replications of this exploratory study are necessary, but these findings provide a first step in understanding how evocative correlations in the home may predict indicators of psychosocial adjustment that in turn influence performance and achievement at school.
\end{abstract}

Early school achievement lays the groundwork for subsequent trajectories of academic, social, and economic success (Entwhisle, Alexander, \& Olson, 2005; Kerckhoff, 2007), yet there are still many unanswered questions regarding its predictors. Most extant research has focused on the cognitive and academic precursors to success in the classroom, such as qualities of the home environment that are believed to stimulate cognitive growth and promote academic achievement (Griffin \& Morrison, 1997; Stipek \& Ryan, 1997), as well as on intrinsic abilities linked to executive functioning (i.e., paying attention, following instructions, inhibiting inappropriate actions; DiPerna, Lei, \& Reid, 2007; Ladd, Birch, \& Buhs, 1999; Lin, Lawrence, \& Gorrell, 2003; McClelland et al., 2007).

An emerging line of research focuses on children's socialemotional behavior in the classroom as another crucial component of academic performance and achievement (e.g., Graziano, Reavis, Keane, \& Calkins, 2007). Children and adolescents who have difficulty regulating emotion (i.e., negativity, frustration) in the classroom or who exhibit high levels of externalizing and internalizing behaviors (see Masten et al.,

This study was funded by the National Science Foundation through a Children's Research Initiative grant (BCS-0126475) and an Integrative Research Activities for Developmental Science Grant (BCS-0720660). The authors thank all of the parents who participated in the Durham Child Health and Development Study and the research assistants for their valuable help in collecting this data.

Address correspondence and reprint requests to: Cathi Propper, Center for Developmental Science, 100 East Franklin Street, CB 8115, University of North Carolina at Chapel Hill, Chapel Hill, NC 27599-8115; E-mail: propper@unc.edu.
2005, for review) are at increased risk for poor adjustment to the classroom context, which may lead to future difficulties with social and academic competence (Blair \& Peters, 2003). Although many of these studies focus on the classroom behavior and performance of students in the later grades of elementary school and through high school, the critical skills that contribute to functioning in this context begin to develop early in the life course. Forty-six percent of a large, national sample of teachers reported that more than half of the children entering kindergarten classes did not possess the basic regulatory competencies needed to do well in school (Rimm-Kaufman, Pianta, \& Cox, 2000).

Little is known about the origins of these competencies in the first years of school. The present study examines early predictors of academic achievement and performance in first grade, with a focus on one possible source of variability: a gene-environment correlation involving mother and child genotype and maternal caregiving over the first 3 years of life. We hypothesize that these correlations are associated with psychosocial behavior and functioning (i.e., emotion regulation, externalizing behavior, internalizing behavior) that are integral to success in the classroom.

We focus on two dopamine receptor polymorphisms associated with receptor Types 2 (DRD2) and 4 (DRD4), because of the evidence linking them to impulsive behaviors and diminished capacity to learn from mistakes (Type 2; e.g., Eisenberg et al., 2007; Frank, Moustafa, Haughey, Curran, \& Hutchinson, 2007) and symptoms of attention-deficit/hyperactivity disorder (Type 4; for a recent meta-analysis, see Smith, 2010). Dopamine receptors may be related to processes that are associated 


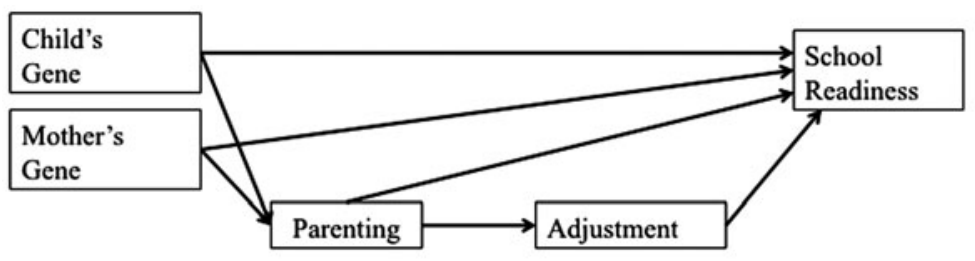

Birth 6-36 Months $\quad 60,72$ Months $\quad 72$ Months

Figure 1. The pathways that the dopamine receptors take: whether these polymorphisms evoke less positive, sensitive parenting across the first 3 years of life, whether such parenting then eventuates in psychosocial skills that are less conducive to the social setting of the classroom, whether teachers evaluate these children in the classroom as less capable students, and whether these students have lowered standardized test scores.

with behavioral control, learning, and motivation (e.g., Benjamin et al., 1996; Wise, 2004), and one study, drawing on a nationally representative sample, reports that DRD2 TaqIA is associated with educational continuation in late adolescence (Shanahan, Vaisey, Erickson, \& Smolen, 2008).

As shown in Figure 1, we examine whether these polymorphisms evoke less positive, sensitive parenting across the first 3 years of life, whether such parenting then eventuates in psychosocial skills that are less conducive to the social setting of the classroom, whether teachers evaluate these children in the classroom as less capable students, and whether these students have lowered standardized test scores. These were assessed via the reading and math subscales of the Woodcock-Johnson Test of Achievement, Third Edition (WJ-III, First Grade; Woodcock, McGrew, \& Mather, 2001).

\section{Psychosocial Skills and Success in the Classroom}

Although cognitive skills clearly matter for academic performance, most learning takes place in the complex social setting of the school and thus reflects the child's psychosocial skills as well, including emotion regulation, externalizing behavior, and internalizing behavior.

Emotion regulation is increasingly viewed as critical for a successful transition to school and academic achievement in early childhood and beyond (Bull \& Sherif, 2001; Fuchs et al., 2003; McClelland et al., 2007). Findings suggest that children who have difficulty regulating emotions have trouble learning in the classroom and are less productive and accurate when completing assignments (Graziano et al., 2007). Evidence also suggests that children who are better at dealing with frustration during the school day may be more likely to stay on task and focus attention on learning (Martin et al., 1983; Newman, 1998). Other findings reveal that the ability to handle frustration and negative emotions appropriately may be an important protective factor leading to better academic performance in children from low socioeconomic status backgrounds (Bramlett, Rowell, \& Mandenberg, 2000; Dobbs, Doctoroff, Fisher, \& Arnolds 2006). Furthermore, intense emotions may affect the studentteacher relationship; children who are less emotionally intense are rated by teachers as being more teachable, and these children achieve at higher levels than children without these emotions (Keogh, 1992; Palinsin, 1986).

There is also considerable evidence linking externalizing behavior to academic achievement (Bardone, Moffitt, Caspi, Dickson, \& Silva, 1996; Chen, Rubin, \& Li, 1997; Dodge \& Pettit, 2003; Hinshaw, 1992; Maguin \& Loeber, 1996; Masten et al., 2005; Normandeau \& Guay, 1998; Risi, Gerhardstein, \& Kistner, 2003; Williams \& McGee, 1994). Moreover, internalizing symptoms such as anxiety, depression, fearfulness, and withdrawn behavior have also been linked to academic problems, although the evidence is more limited and less consistent than for externalizing behavior (Masten et al., 2005). Moderate to strong correlations between internalizing behavior problems in children and daily classroom performance have been reported in clinical and community samples (Brumback, DietzSchmidt, \& Weinberg, 1977; Edelsohn, Ialongo, WerthamerLarsson, Crockett, \& Kellam, 1992; Hodges \& Plow, 1990; Ialongo, Edelsohn, Werthamer-Larsson, Crockett, \& Kellam, 1995; Ollendick, Weist, Borden, \& Greene, 1992).

Many studies of the factors that predict childhood psychopathology focus on externalizing behaviors (e.g., Fleming, Harachi, Cortes, Abbott, \& Catalano, 2004; Hill, Degnan, Calkins, \& Keane, 2006), although childhood internalizing problems are also a serious concern (Masten et al., 2005). In addition, extant studies have typically focused on a single level of analysis (i.e., physiological, cognitive, or behavioral), a single context (i.e., lab, home, or school), or a single time point, and thus do not permit a comprehensive investigation of how these behaviors develop across different levels. The present study, therefore, examines development of the aforementioned behaviors (emotion regulation, externalizing and internalizing) in the classroom, and subsequent academic performance, from a multilevel perspective that takes into account the interplay between child genotype and the early caregiving environment over the first 3 years of life.

\section{Dopamine Receptor Polymorphisms and Psychosocial Adjustment}

Dopamine has been suggested as an underlying neurotransmitter influencing the behavioral system of approach in 
adults, including active exploration and approach toward novel stimuli as well as activation and intensity of response in reward situations (Cloninger, 1987; Gray, 1982; Panskepp, 1986; Zukerman, 1994). Two dopamine receptor genes (associated with $D R D 4$ and $D R D 2$ ) have been extensively examined in the literature as correlates of adult, adolescent, and, more recently, child behavior and functioning.

$D R D 4$ is primarily expressed in the limbic areas of the brain that are involved in cognition and emotion. The DRD4 gene contains a repeated sequence polymorphism within its coding sequences that changes the length of the receptor protein that has been shown to have a moderate functional significance (Asghari et al., 1994). Individuals with longer versions of the polymorphism (L-DRD4; 6-8 repeats) have shown significantly higher novelty-seeking (including risk taking) behaviors than those with the shorter version (S-DRD4; 2-5 repeats); the shorter the allele, the more efficient it is in binding dopamine (Plomin \& Rutter, 1998), suggesting that the L-DRD4 allele is a "risk" allele.

Variations in DRD4 have been related to dimensions of adult personality such as excitability, impulsiveness, and high exploratory behavior (Benjamin et al., 1996; Ebstein, Nemanov, Klotz, Gritsenko, \& Belmaker, 1997; Noble et al., 1998), pathological gambling (Pérez de Castro, Ibáñez, Torres, Sáiz-Ruiz, \& Fernández-Piqueras, 1997), and addictive behaviors such as cigarette smoking (Shields et al., 1998) and alcoholism (George, Cheng, Nguyen, Israel, \& O’Dowd, 1993). The emerging body of research examining associations between $D R D 4$ and child behavior has revealed similar findings. L-DRD4 has been related to externalizing problems such as hyperactive-impulsive-inattention (LaHoste et al., 1996; Sunohara et al., 2000), oppositional defiant behaviors (Kirley et al., 2004), and aggressive behaviors (Benjamin, Ebstein, \& Belmaker, 2002; Schmidt, Fox, Rubin, $\mathrm{Hu}$, \& Hamer, 2002) in children and adolescence. Many studies, however, have failed to replicate such associations (e.g., Birkas et al., 2005). Consequently, although there is reason to believe that $D R D 4$ may play a role in the development of behavioral problems, more work is needed to clearly understand the mechanisms involved, including a closer study of how pathways may differ for different demographic groups (e.g., race, socioeconomic status, sex) and how the interplay between genes and environment may lead to multiple outcomes.

The risk allele of $D R D 2$ (i.e., minor $T a q 1 \mathrm{~A} 1$ allele) has been related to several similar dimensions of adult and adolescent personality, including high novelty-seeking behavior (Cloninger, Adolfsson, \& Svrakic, 1996; Noble et al., 1998; Suhara et al., 2001), conduct disorder (Comings et al., 1996; Lu, Lee, Ko, \& Lin, 2001), impulsivity (Wiers, Sergeant, \& Gunning, 1994), and disinhibition (McGue, Slutske, Taylor, \& Iacono, 1997). ${ }^{1}$

1. Because the TaqIA site lies $10 \mathrm{~kb}$ downstream of DRD2, Neville, Johnstone, and Walton (2004) suggested that it may fall within a different coding region than the $D R D 2$ gene or within a regulatory region. They determined that the TaqIA SNP occurs in exon 8 of the ANKK1 gene, and results in a glu713 to lysine (E713K) substitution within the 11th ankyrin repeat of ANKK1. TaqIA's effects on D2 functioning appears to be medi-
Furthermore, this allele of $D R D 2$ has also been associated with addictive behaviors such as pathological gambling (e.g., Comings et al., 1996), alcoholism (Blum et al., 1991; Noble et al., 1994), nicotine dependence (Comings et al., 1996; Noble et al., 1994), and opiate dependence (Lawford et al., 2000). These results are consistent with expectations, as the Taq $1 \mathrm{~A} 1$ allele of $D R D 2$ has been reported to be associated with a decrease in D2 dopamine receptor availability (Pohjalainen et al., 1998), and the number of receptor binding sites is lowest in A1 homozygotes. Therefore, given that $\mathrm{D} 2$ dopamine receptors have an inhibitory function in the dopaminergic system, a lower availability of these receptors may translate into less behavioral control. In addition to behavioral associations, a previous study of the current sample found that the risk allele of DRD2 was associated with less effective parasympathetic regulation (i.e., respiratory sinus arrhythmia), a purported physiological index of behavioral and emotional regulation, over the first year of life (Propper et al., 2008).

In summary, the DRD2 and DRD4 dopamine receptor genes are associated with personality characteristics and clinical disorders that are impulsive, reward seeking, and addictive in nature. The present study focuses on these two genes because these characteristics, overall, appear to be related to a lack of regulatory ability and behavioral control, which are critical skills for successful performance in the classroom.

\section{The Mediating Link: Gene-Parenting Correlations and Adjustment}

Our conceptual model (Figure 1) posits that parenting is a critical mediator between genetic propensities and adjustment and academic performance. A multitude of findings reveal that the first years of life are a fundamental time for the emergence of regulatory processes that underlie healthy social-emotional and cognitive development (e.g., Moore et al., 2009). Although infants have rudimentary self-regulatory abilities, they initially rely on their parents for support in regulating behavior and internal physiological homeostasis (Spangler \& Grossman, 1993; Spangler, Schiechle, Ilg, Maier, \& Ackerman, 1994), and as they grow and develop, they may progressively internalize the regulation strategies used within the dyad during the earlier months (Calkins, Smith, Gill, \& Johnson, 1998; Thompson, 1994). The way in which caregivers respond to the needs of their children may influence the independent ability to modulate stress and lead to more adaptive methods of regulation over time (Derryberry \& Rothbart, 1984). Through repeated, day-today caregiving, early interactions influence the trajectory of young children's behavioral and physiological regulatory abilities (e.g., Haley \& Stansbury, 2003; Moore and Calkins, 2004; Propper \& Moore, 2006; Propper, Willoughby, Halper, Carbone, \& Cox, 2007).

ated by indirect linkage with other $D R D 2$ polymorphisms, including C957T (Frank \& Hutchinson, 2009; Zhang et al., 2007). 
Similarly, some of the most robust predictors of childhood externalizing behaviors are harsh or insensitive parenting (Booth, Rose-Krasnor, McKinnon, \& Rubin, 1994), maternal depression and interaction style (Leadbeater, Bishop, \& Raver, 1996), and parent-child relationships that are relatively low in warmth (Olson, Bates, Sandy, \& Lanthier, 2000). The early years of life are of particular importance; caregiving as early as infancy has been significantly associated with externalizing problems, such as conduct and oppositional disorders, at school entry (Shaw, Owens, Giovannelli, \& Winslow, 2001). Similarly, internalizing problems in children have been associated with early maternal parenting behavior such as negativity toward the child, hostility, low warmth, and inconsistent availability (Cicchetti \& Toth, 1995; Hammen \& Rudolph, 1996). The current study investigates maternal sensitivity from 3 to 36 months of age as a potential contributor to externalizing and internalizing outcomes in early childhood.

Although critical, parenting does not work independently, nor is it a unidirectional process. Family systems theory highlights the nature of parenting as a social behavior, directed toward and influenced by characteristics of the child (Belsky, 1984; Cox \& Paley, 2003). In this sense, the developmental origins of variations in parenting behaviors must focus not only on the parent but also on the role of the child and the broader environment in which they live. Prior to genetically informed studies of parenting and child development, there was evidence that child characteristics may evoke variations in maternal caregiving. For example, Crockenberg (1981) and van den Boom (1994) reported that highly irritable infants tend to receive less sensitive care and are at greater risk for developing insecure relationships. Furthermore, whereas sensitive parenting can be challenged and reduced by child negativity, it can be enhanced when the child positively stimulates the parent and responds to her bids for interaction (see also Atkinson et al., 1999; Cox, Owen, Henderson, \& Margand, 1992; Kochanska, 2001; Thompson, 1997; van den Boom, 1997). Attentive children who respond positively to their mothers tend to elicit more sensitive caring, warmth, and attention from them than children who are highly reactive and not easily soothed (Thompson, 1997; van den Boom, 1997; Shamir-Essakow, Ungerer, Rapee, \& Safier, 2004).

Given the consolidating effect of child temperament and behavior on parenting, it is important to understand the role, if any, that genetic polymorphisms associated with specific temperamental and personality traits play in this process and whether their presence in the child, the mother, or both parties affects parenting behaviors. The current paper investigates the contribution of two such processes to the development of behavior in the classroom and subsequent performance, "evocative" and "passive" gene-environment correlations ( $r$ GE; Rutter \& Silberg, 2002). An evocative $r \mathrm{GE}$ refers to the way in which the child genotype may evoke or elicit reactions from others, including caregivers (Plomin, DeFries, \& Loelin, 1977; Scarr \& McCartney, 1983). A passive correlation (Rutter, Moffitt, \& Caspi, 2006) refers to an association between the genotype inherited from the parent and the child-rearing environment as influenced by the parent. Jaffee and Price's (2007) review notes that dimensions of parenting are moderately heritable, although the specific molecular basis for these associations is not well studied.

Two prospective studies, however, have reported correlations between polymorphic variants in the child and the caregiving of the parent. First, Propper et al. (2007) found that children with the long variant of a DRD4 gene received less sensitive caregiving (although not more harsh caregiving) than did children with the short variant of the same gene. However, this study did not have the data to conclude whether this correlation between child gene and parenting behavior was the result of evocative or passive genetic effects. However, variations in this gene have been associated with individual differences in infant engagement and activity levels (Cloniger, 1987; Ebstein et al., 1998), characteristics that may evoke differential responding from mothers.

Second, another study found that children with the $\mathrm{A}_{1}^{+}$allelic variant of the $D R D 2$ gene received significantly less sensitive caregiving than children with the $\mathrm{A}_{1}^{-}$variant (MillsKoonce et al., 2008). In this study, the effect of child gene was independent of the effects of maternal gene, suggesting that the association was evocative and not passive in nature. Dick, Rose, and Kaprio (2006) identified a mediator of a potentially evocative gene-environment correlation between child genotype (a DRD2 receptor variant) and retrospective report of their receipt of care from mothers and fathers. Specifically, those with the exon 8-A DRD2 allele reported receipt of significantly more paternal rejection and maternal and paternal overprotectiveness, effects partially mediated by their self-report of temperament. Unfortunately, this study did not include parental genotype controls and relied on retrospective self-report (which is prone to perceptual biases) as opposed to more objective (and prospective) observations of behavior (see also Lucht et al., 2006, which reports gene-environment correlations involving $D R D 2$ and parenting).

Finally, there is some evidence for sex differences in dopamine release and behavioral response (Martin-Soelch et al., 2011). Behavioral correlates of dopamine activity have been found to be more pronounced in males compared to females, perhaps reflecting differences in the biological substrate as well as socialization. For example, men exhibited greater dopamine release then women following the administration of amphetamine and rated the effects of the drug as more pleasurable (Munro et al., 2006). Similarly, women also have lower D2 receptor affinity than men, which suggests a further mechanism to explain why men's addictive-related disorders are far more common than women's (Pohjalainen, et al. 1998). Thus, an examination of the model shown in Figure 1 by sex may be revealing.

\section{The Current Study}

The current study examines the interplay between child and mother dopamine genes and early maternal parenting behav- 
iors as a predictor of psychosocial functioning in the kindergarten and first-grade classrooms (as rated by teachers). Understanding this gene-parenting correlation will provide insight into the critical mechanisms and pathways involved in the development of behaviors known to be essential for adjusting to the classroom context at school entry. This geneenvironment correlation, as well as resulting child behaviors in the classroom, may be key a mediator of academic success or failure in early elementary school and beyond.

The current study thus tests the meditational model shown in Figure 1. We examine (a) possible gene-environment correlations involving the dopamine receptor polymorphisms and parenting; (b) whether these correlations predict central indicators of adjustment, including externalizing behavior, internalizing behavior, and emotion regulation; and (c) whether parenting and/or these indicators of adjustment are associated with behaviors and cognitive abilities observed in the classroom in first grade. Thus, this longitudinal study will draw upon genotype, observational measures of maternal parenting behavior, teacher report of behavior and performance in the classroom, and a standardized laboratory assessment of academic achievement from 3 months to 8 years of age in order to better understand the multiple levels and pathways that lead to early school success at first grade.

\section{Methods}

\section{Participants}

Participants were drawn from the Durham Child Health and Development Study, a longitudinal sample consisting of 206 healthy, full-term infants who were followed from 3 months to 8 years of age. Families were recruited from a largely urban community via fliers and postings at birth and parenting classes, as well as through phone contact via birth records. Approximately equal numbers of European American (EA) and African American (AA) families were sampled from low- and high-income groups. Infant's race was determined by the mother (or primary caregiver); income status was assessed based on the size of the family in relation to their household income in accordance with the 2002 Federal Poverty Guidelines. Demographic information was collected during the first visit at 3 months of infant age and was updated at each subsequent visit. Parents also consented for study staff to contact their child's kindergarten and first-grade classroom teachers. Teachers completed consent forms and questionnaires by mail.

The present study uses data from laboratory visits that occurred when infants were 6, 12, 24, and 36 months of age and in their kindergarten and first-grade years. The current analyses include child and mother genetic data (DRD2/ $D R D 4$ ), maternal parenting data from 6 to 36 months, teacher report of child behavior in kindergarten and first grade, and academic outcomes measured via teacher report and the WJ-III at first grade. The final sample $(N=166)$ is made up of 81 females and 85 males, of which 93 were AA and
73 were EA. Eighty-five families reported incomes that were classified as below poverty and 81 as above. At recruitment, the mean age of mothers was $27.8(S D=5.63$, range $=$ 18-40 years), and $51 \%$ of mothers reported having some college education, $49 \%$ had a high school education or some vocational training, and $44 \%$ of mothers were currently employed.

Of the 166 dyads with complete genetic and race data, all had parenting data for at least 1 of the visits across 6 to 36 months, 117 completed the WJ-III in first grade, and 95 had teacher report at either kindergarten or first grade. Girls and boys with and without teacher ratings were compared on all variables, and only one mean level difference was observed (among boys, those missing teacher ratings were more likely to be low income when compared to boys with teacher ratings). There were several apparently random reasons for missingness on teacher ratings, suggesting that missingness on teacher ratings is not systematically biased.

\section{Procedure}

At the 6-, 12-, 24-, and 36-month visits, infants and their mothers participated in several joint and individual tasks followed by a standardized interview and completion of demographic questionnaires by mothers. Infant and maternal genetic data was obtained at the 12-month visit, and maternal parenting behavior was coded during free-play interactions at each of these visits. At kindergarten and first grade, classroom teachers were contacted and asked to report on child behavior in the classroom. Finally, the letter-word and applied problems subscales of the WJ-III were administered in the lab at first grade.

\section{Measures}

\section{Parenting.}

Mother-infant free play (6-, 12-, 24-, and 36-month lab visits). To evaluate maternal behavior during interactions with infants, mothers were provided a standard set of toys and instructed to interact with their children as they normally would if playing during some free time on a typical day. The task lasted $10 \mathrm{~min}$ and was videotaped for later coding.

Free-play interactions were coded by two independent coders who were unaware of the study's hypotheses. From these observations, seven subscales of maternal behavior were coded (sensitive responsiveness, intrusiveness, detachment, positive regard, negative regard, stimulation of cognitive development, and animation). Coders were trained to reliability until interclass correlation coefficients of 0.80 or greater were established and maintained with criterion coders (and for each individual pair of coders). All interactions were double coded, and final scores were agreed upon by conferencing. An overall maternal sensitivity composite was created (guided by factor analyses) by aggregating the scores for five of the subscales, including sensitivity/responsiveness, 
positive regard stimulation of development, animation, and detachment/disengagement (reverse scored). Similar composite scores for maternal sensitivity have been used by the National Institute of Child Health and Human Development Study of Early Child Care (1997), the Family Life Project (Blair, Granger, Willoughby, Kivlighan, \& The Family Life Project Key Investigators, in press), and other reports based on the current Durham Child Health and Development Study sample.

Sensitive parenting was modeled using a latent variable approach in which the measure of sensitive parenting for each time point $(6,12,24$, and 36 months) was loaded onto a latent factor for sensitive parenting. The factor loading for 6 months was set at 1 to set the metric of the latent variable, and the factor loadings for 12,24 , and 36 months were then estimated.

Child behavior in classroom. Teachers were mailed questionnaires with items related to child's behavioral, emotional, and academic performance in the classroom in kindergarten and first grade. The following questionnaires were included in the current analyses.

Child Behavior Checklist Teacher's Report Form (CBCLTRF; kindergarten and first grade). Teachers reported on child behavior using the CBCL-TRF (Achenbach \& Rescorla, 2001), a standardized 120-item questionnaire that obtains ratings of children's behavioral/emotional problems. The reliability and validity of the CBCL-TRF has been widely established for assessing psychopathological symptoms in youths (e.g., Bérubé \& Achenbach, 2001; Grigorenko, Geiser, Slobodskaya, \& Francis, 2010). For each item, the respondent was asked to determine how well that item describes their student currently or within the last 6 months using a scale of not true to very often true. Final scores used in analyses were the mean of the kindergarten and first grade subscales of the CBCL-TRF.

Because of our interest in identifying specific behaviors that may mediate the relationship between $r \mathrm{GE}$ and academic performance, scores on the following five subscales (that contribute to externalizing and internalizing behavior) were included in preliminary analyses: withdrawn behavior, somatic complaints, anxious/depressed, delinquent behavior, and aggressive behavior. Although we run the risk of capitalizing on chance by including each of these five subscales in our analyses, it is important to note that all mean level differences between groups defined by $D R D 2$ and $D R D 4$ allele status were of considerable size (and standard deviations were large, likely reflecting the small sample size). Preliminary analyses revealed that significant differences by genetic risk were found only in withdrawn behavior; therefore, this subscale is the only one included in the models described below. Moreover, a recent study provides evidence for this same pattern, further supporting our focus on withdrawal (Marino et al., 2004).
Emotion Regulation Checklist (ERC; kindergarten and first grade). Teachers completed the ERC (Shields \& Cicchetti, 1997, 2001), which assesses teachers' perceptions of child emotionality and regulation. This measure includes 24 items that are rated on a 4-point Likert scale indicating how frequently the behaviors occur $(1=$ almost always to $4=$ never). The ERC contains items examining both positive and negative aspects of emotion regulation (e.g., "is easily frustrated," "transitions well from one activity to another," and "doesn't become angry, anxious, distressed, or overall excited"). Six items were reverse scored such that a higher score was always indicative of more positive behavior.

The results of previously reported factor analyses (see Shields \& Cicchetti, 1998) indicate that two factors emerge: lability/negativity and emotion regulation. Shields and Cicchetti (1997) reported high internal consistency (Cronbach $\alpha$ for liability/negativity $=0.96$, emotion regulation $=$ 0.83 ) and validity of the ERC using correlations with observers' ratings of children's regulatory abilities. The current study focused on the emotion regulation factor, which assesses appropriate display of emotion, identification with the feelings of others, and awareness of one's own emotional state (i.e., is a cheerful child, is empathic toward others, shows concern when others are upset or distressed). For the current study, scores were calculated as the mean of teacher responses (including reverse scored items) to the 8 items that load onto the emotion regulation factor. Final scores used in analyses were the mean of the kindergarten and first grade scores on the emotion regulation subscale.

\section{Academic achievement and performance.}

Academic Achievement and Performance Rating Scale (APRS, First Grade). The APRS (DuPaul, Rapport, \& Perriello, 1991) is a 19-item scale that was developed to reflect teachers' perceptions of children's academic performance and abilities in classroom settings. It includes items assessing work performance in various subject areas (e.g., "Estimate the percentage of written math work completed relative to classmates"), academic success (e.g., "What is the quality of this child's reading skills?"), behavioral control in academic situations (e.g., "How often does the child begin written work prior to understanding the directions?"), and attention to assignments (e.g., "How often is the child able to pay attention without you prompting him/her?"). Teachers answered each item using a 1 (bottom $0 \%-49 \%$, or very slowly/consistently poor) to 5 (top 90\%-100\%, quickly/consistently successful) Likert-scale format.

Previous studies (DuPaul et al., 1991) have reported that the 19 items load onto three statistically unique student abilities/factors: (a) academic success (i.e., quality of students classroom work), (b) impulse control (i.e., ability to control behaviors in academic situations), and (c) academic productivity (i.e., ability to complete work regardless of quality). DuPaul et al. (1991) found that congruent coefficients within factor items ranged from 0.84 to 0.98 with a mean of 0.92 , 
and strong intercorrelations existed between subscales (range $=0.69-0.88$ ). Due to these high intercorrelations, the present study used the APRS total score (sum of all items) as the teacher rating of academic performance and achievement.

WJ-III. The WJ-III (Woodcock et al., 2001) is a nationally normed test that has been widely used in studies of early education and achievement, including studies with racially and socioeconomically mixed samples. All children completed two standardized subtests from the WJ-III as an assessment of intellectual ability: math (applied problems [WJ-AP]) and reading (letter-word [WJ-LW]). The LW identification subtest measures prereading and reading skills. It requires children to identify letters that appear in large type and to pronounce words correctly (the child is not required to know the meaning of any particular word). In previous research, scores from this measure have shown internal reliability of 0.98 for 4- and 6-year-olds (Mather \& Woodcock, 2001). The AP subtest requires the child to analyze and solve math problems, performing relatively simple calculations, as a measure of early math reasoning and problem-solving abilities. This test includes orally administered word problems accompanied by pictures. Children are provided with a paper and pencil, and they must listen to the item, recognize the procedure to be followed, and perform the appropriate calculations before responding. All subtests include items increasing in difficulty and were administered until children reached a ceiling level (e.g., six items incorrect in a row). Scores from this measure have shown internal reliability of 0.92 among 5- and 6-yearolds (Mather \& Woodcock, 2001). Raw scores (i.e., the sum of correct answers within a subtest) were converted to gradebased standard scores for each subtest using WJ-III computerized scoring technology (Mather \& Woodcock, 2001).

Genotyping (12 months). DNA was obtained through the collection of infant and mother buccal cells (i.e., cheek cells). The experimenter put on latex gloves before handling any supplies and rubbed the inside of the infants' inner cheek and gums for $20 \mathrm{~s}$ with a Q-tip. The Q-tip was then immediately placed into a pint-sized Zip-loc bag, sealed, and put into a storage freezer where it remained until sent to the laboratory for processing. Cheek cells for DNA isolation and analysis were sent to a genetics laboratory at North Carolina State University, Raleigh, North Carolina. In order to assure quality control, samples were analyzed twice per genotype and results were double entered into the database. All of the genotyping was done blind to the study's hypotheses and outcomes.

Genomic DNA was extracted from each salivary sample using the Puregene DNA extraction kit by following the manufacturer's protocol for DNA isolation from $1 \mathrm{ml}$ of body fluid. Saliva samples yielded DNA in adequate quantities for genotyping $(\sim 200 \mu \mathrm{g} / \mathrm{ml})$. Genotyping of the 48 base pair repeat in exon III of the DRD4 gene was performed as previously described. The genotypes short/short (s/s), s/ long $(\mathrm{s} / \mathrm{l})$, or $1 / 1$ were assigned to each individual. Based on previous results (Anchordoquy, McGeary, Liu, Krauter, \& Smolen, 2003; Benjamin et al., 1996; Schmidt et al., 2002), polymorphisms made up of homogeneous short alleles (s/s) were classified as short (S-DRD4) and heterogeneous polymorphisms (s/l and 1/l) were classified as long (L$D R D 4)$. DRD4 genotyping for mothers and children was in Hardy-Weinberg equilibrium.

Genotyping of the DRD2 gene was performed by polymer chain reaction amplification using the forward and reverse primers: $5^{\prime}$-ccgtcgacggetggccaagttgtcta $(\mathrm{D} 2 \mathrm{~F} 1)$ and $5^{\prime}$ ccgtcgaccettcctgagtgtcatca (D2R1; Miyake et al., 1999). The amplicon was subsequently digested with the restriction enzyme, Taq1 (New England Biolabs, MA). This results in digestion products of the A1 allele (310 base pairs) and the A2 allele $(180+130$ base pairs). The allele status of DRD2 $\mathrm{A}_{1}^{+}\left(\mathrm{A}_{1} / \mathrm{A}_{1}\right.$ and $\mathrm{A}_{1} / \mathrm{A}_{2}$ genotypes $)$ and $\mathrm{A}_{1}^{-}\left(\mathrm{A}_{2} / \mathrm{A}_{2}\right.$ genotype) were assigned to each individual based on previous studies (see Noble, 2003). DRD2 genotyping for mothers and children was in Hardy-Weinberg equilibrium.

\section{Analytic strategy}

Structural equation models were estimated to examine the conceptual model shown in Figure 1. The analytic strategy was designed to identify specific measures of parenting, adjustment, and school performance/achievement for this model, and then to estimate the model shown in Figure 1, incorporating these specific genetic, behavioral, and environmental candidates. Preliminary analyses examined patterns of missing data and distributional properties of candidates. Prior research suggested the importance of $D R D 2$ and $D R D 4$ for parenting and, in the case of $D R D 2$, for educational processes among boys (Shanahan et al., 2008). We thus focused on these two candidates, examining mean level differences between groups defined by $D R D 2$ and $D R D 4$ allele status on variables reflecting parenting, adjustment, and school performance/achievement. These analyses suggested unique, specific candidates for boys and girls. Path models were thus estimated separately for boys and girls with MPlus (version 6.12) using full-information maximum-likelihood estimation to address bias resulting from missing data.

\section{Results}

\section{Distributions of the dopamine receptor polymorphisms}

Table 1 reports the distribution of the DRD2 and DRD4 alleles. Mothers with the $D R D 2 \mathrm{~A}_{1}^{+}$allele were about twice as likely to have children with $\mathrm{A}_{1}^{+}$than with $\mathrm{A}_{1}^{-}\left(\chi^{2}=\right.$ $30.01, p<.001)$. Mothers with the $\mathrm{A}_{1}^{-}$allele were almost three times more likely to have children with the $A_{1}^{-}$than with $\mathrm{A}_{1}^{+}$. A comparison of this distribution of alleles with that observed in the National Longitudinal Study of Adolescent Health (Add Health, Wave III) reveals a similar mix of $\mathrm{A}_{1}^{+}$and $\mathrm{A}_{1}^{-}$(calculations available on request). The allele distributions for $D R D 2$ also differ by race (not shown), with AAs 
Table 1. Distribution of mother and child dopamine receptor D2 (DRD2) and D4 (DRD4) polymorphisms

\begin{tabular}{lcc}
\hline \hline & Mother DRD2 $\mathrm{A}_{1}^{-}$ & Mother DRD2 $\mathrm{A}_{1}^{+}$ \\
\hline Child DRD2 $\mathrm{A}_{1}^{-}$ & 56 & 32 \\
Child DRD2 $\mathrm{A}_{1}^{+}$ & 17 & 62 \\
\hline & Mother DRD4 $\mathrm{A}_{1}^{-}$ & Mother DRD4 $\mathrm{A}_{1}^{+}$ \\
\hline Child DRD4 $\mathrm{A}_{1}^{-}$ & 74 & 28 \\
Child DRD4 $\mathrm{A}_{1}^{+}$ & 20 & 41 \\
\hline \hline
\end{tabular}

Note: Mothers with DRD2 $\mathrm{A}_{1}^{+}$are more likely to have children with DRD2 $\mathrm{A}_{1}^{+}\left(\chi^{2}=30.01, p<.001\right)$, and mothers with $D R D 4 \mathrm{~A}_{1}^{+}$are more likely to have children with $D R D 4 \mathrm{~A}_{1}^{+}\left(\chi^{2}=24.72, p<.001\right)$.

being somewhat more likely to carry $\mathrm{A}_{1}^{+}$, which was also observed in Add Health. Females are also somewhat more likely to carry the nonrisk variant than males, which is also observed in Add Health.

Table 1 also shows the distribution of the $D R D 4$ alleles and reveals that the mothers with the $D R D 4 \mathrm{~A}_{1}^{-}$allele were over three times more likely to have children with $\mathrm{A}_{1}^{-}$than with $\mathrm{A}_{1}^{+}\left(\chi^{2}=27.72, d f=1, p<.001\right)$. A comparison of this distribution of alleles with that observed in Add Health reveals that the two are very comparable. The allele distributions for $D R D 4$ do not differ markedly by race, although females are more likely to carry the risk variant.
Descriptive statistics and correlations among the covariates

Table 2 reports descriptive statistics and mean level differences by allele status for the variables of central interest. For the girls, mean levels of sensitive parenting differ significantly by $D R D 4$ status; by comparison, parenting differs for boys by $D R D 2$ status. All significant mean level differences for the girls are observed for DRD4 allele status, and all such differences for the boys reflect $D R D 2$ status. Girls' withdrawn behavior at kindergarten differs significantly, and the magnitude of the difference is considerable. Thus, teachers evaluate girls with $D R D 4$ risk as more shy, less interactive, and lonelier when compared to girls without DRD4 risk. For the boys, mean level differences are observed for emotion regulation at kindergarten, suggesting that boys with $D R D 2$ risk are more easily frustrated and prone to anger and excitement, for example, than their DRD2 nonrisk counterparts. The difference in emotion regulation at first grade also appears large, but the standard errors are also large. (Several of the other indicators of adjustment show apparently large mean level differences, but they do not differ significantly because of large standard deviations.)

Among the indicators of school performance, the APRS and WJ-LW differ by DRD4 status for the girls, and the differences are notable in magnitude. Among the boys, both WJ subscales (WJ-LW and WJ-AP) differ significantly. These results thus show a clear pattern: DRD4 allele status distin-

Table 2. Means and standard deviations of covariates by gender and dopamine receptor D2/D4 (DRD2/DRD4) risk

\begin{tabular}{|c|c|c|c|c|c|c|c|c|}
\hline & \multicolumn{4}{|c|}{ Girls } & \multicolumn{4}{|c|}{ Boys } \\
\hline & \multicolumn{2}{|c|}{ DRD2 } & \multicolumn{2}{|c|}{ DRD4 } & \multicolumn{2}{|c|}{$D R D 2$} & \multicolumn{2}{|c|}{ DRD4 } \\
\hline & Risk & No Risk & Risk & No Risk & Risk & No Risk & Risk & No Risk \\
\hline \multicolumn{9}{|c|}{ Parenting $(6,12,24, \& 36$ months $)$} \\
\hline Sensitive parenting & 3.22 & 3.34 & 3.09 & $3.44 *$ & 3.01 & $3.37 * *$ & 3.17 & 3.21 \\
\hline Adjustment & 0.72 & 0.69 & 0.70 & 0.69 & 0.63 & 0.62 & 0.70 & 0.62 \\
\hline Emotion regulation $(\mathrm{K})$ & 3.25 & 3.32 & 3.18 & 3.40 & 2.81 & $3.14 *$ & 2.75 & 3.05 \\
\hline$S D$ & 0.33 & 0.45 & 0.46 & 0.24 & 0.27 & 0.33 & 0.13 & 0.34 \\
\hline Emotion regulation (1st) & 3.15 & 3.34 & 3.20 & 3.28 & 2.91 & 3.20 & 3.12 & 3.10 \\
\hline$S D$ & 0.57 & 0.38 & 0.50 & 0.52 & 0.63 & 0.51 & 0.77 & 0.52 \\
\hline Withdrawn behavior (K) & 1.00 & 1.38 & 1.67 & $0.64 *$ & 2.33 & 1.32 & 3.00 & 1.54 \\
\hline$S D$ & 1.46 & 1.33 & 1.68 & 0.75 & 3.08 & 2.47 & 2.83 & 2.69 \\
\hline Withdrawn behavior (1st) & 1.63 & 1.20 & 1.40 & 1.48 & 2.45 & 1.18 & 2.00 & 1.63 \\
\hline$S D$ & 2.78 & 1.20 & 2.58 & 1.94 & 3.21 & 1.71 & 3.00 & 2.24 \\
\hline \multicolumn{9}{|l|}{ Outcome (1st) } \\
\hline APRS & 3.57 & 3.77 & 3.70 & $4.11 *$ & 3.57 & 3.77 & 3.72 & 3.68 \\
\hline$S D$ & 0.84 & 0.71 & 0.77 & 0.75 & 0.81 & 0.96 & 0.82 & 0.94 \\
\hline WJ-LW & 113.29 & 113.69 & 109.33 & $117.10 *$ & 106.84 & $116.14 *$ & 109.38 & 112.65 \\
\hline$S D$ & 11.57 & 13.83 & 11.20 & 12.62 & 16.44 & 13.27 & 17.71 & 14.71 \\
\hline WJ-AP & 108.73 & 111.67 & 108.27 & 111.45 & 101.08 & $113.80 * *$ & 109.46 & 108.02 \\
\hline$S D$ & 14.72 & 15.50 & 12.74 & 17.17 & 15.64 & 18.84 & 23.72 & 17.16 \\
\hline
\end{tabular}

Note: K, kindergarten; 1st, first grade; APRS, Academic Achievement and Performance Rating Scale; WJ-LW, Woodcock-Johnson letter word subscale; WJAP, Woodcock-Johnson applied problems subscale.

$*_{p} \leq .05$. ** $p \leq .01$. 
guishes girls and $D R D 2$ distinguishes boys with respect to parenting, an indicator of adjustment, and two indicators of school performance. We thus focused on withdrawn behavior for girls and emotion regulation for boys, and examined models for all three indicators of school performance.

Table 3 reports bivariate associations among the variables chosen for inclusion in the structural equation models for the girls. The girls' DRD4 status is negatively associated with sensitive parenting from 6 to 36 months $(r=-.24, p<$ $.05)$, and the APRS $(r=-.27, p<.05)$ and the WJ-LW $(r=-.31, p<.05)$ in first grade, but not with social withdrawal. There is an appreciable positive correlation between the mother's and daughter's DRD4 status $(r=.36, p<.01)$, raising the possibility of an active gene-environment correlation. Sensitive parenting is highly related to the daughter's withdrawal $(r=-.32, p<.05)$, the APRS $(r=.57, p<$ $.01)$, and the WJ-LW and WJ-AP $(r=.37$ and .49 , respectively, both $p<.01)$. The daughter's social withdrawal is strongly, negatively associated with the APRS $(r=-.53$, $p<.01$ ), but it is unrelated to either scale of the WJ-III. This pattern suggests that first-grade teachers view withdrawn girls as less successful and academically productive. Finally, the APRS and the WJ-III scales are highly intercorrelated, but the magnitudes of the correlations nevertheless suggest that they are tapping unique dimensions of school performance. In sum, the pattern of correlations raises the possibility that girls' DRD4 status is associated directly and indirectly with indicators of school readiness, indirectly through parenting (for APRS, WJ-LW, and WJ-AP) and perhaps through parenting and adjustment (APRS).

Table 3 also reports the bivariate associations for the boys. In contrast to the pattern observed among the girls, DRD2 sta- tus is negatively associated with the two subscales of the $\mathrm{WJ}$, but not the APRS. As observed among the girls, genetic risk is likewise negatively associated with sensitive parenting $(r=$ $-.28, p<.01)$ and emotion regulation $(r=-.29, p<.01)$. The correlation between the son's and mother's DRD2 status is substantial $(r=.52, p<.01)$, once again suggesting a possible active gene-environment correlation and the importance of statistical control. Mother's sensitive parenting is associated with emotion regulation $(r=.29, p<.05)$ and the $\mathrm{WJ}-\mathrm{AP}(r=.44, p<.01)$. In turn, emotion regulation is substantially correlated with the APRS $(r=.69, p<.001)$, the WJ-LW $(r=.37, p<.01)$, and the WJ-AP $(r=.46, p<$ $.01)$. As observed among the girls, the correlations indicate that although the APRS, WJ-LW, and WJ-AP are highly intercorrelated, they are also tapping unique features of school performance. This overall pattern raises the possibility that $D R D 2$ status is directly and indirectly associated with indicators of school performance, indirectly through parenting (for WJ-AP) and possibly through parenting and emotion regulation (for APRS, WJ-LW, and WJ-AP).

The bivariate patterns again clearly suggest the importance of DRD4 and DRD2 for females and males, respectively, for parenting, indicators of adjustment, and school performance in the first grade. Given these bivariate patterns, we examined the structural equation model suggested by Figure 1 focusing on $D R D 4$ and social withdrawal for females and $D R D 2$ and emotion regulation for males.

\section{DRD4 and school performance: Females}

In interpreting the model's path parameters, we report standardized estimates and one-tailed $p$ values; the latter decision

Table 3. Bivariate correlations for boys and girls

\begin{tabular}{|c|c|c|c|c|c|c|c|c|}
\hline & 1 & 2 & 3 & 4 & 5 & 6 & 7 & 8 \\
\hline \multicolumn{9}{|l|}{ Girls } \\
\hline 1. $D R D 4$ risk & - & & & & & & & \\
\hline 2. Race & .06 & - & & & & & & \\
\hline 3. Mother's $D R D 4$ risk & $.36^{* *}$ & .01 & - & & & & & \\
\hline 4. Sensitive parenting (mean of $6,12,24, \& 36$ months) & $-.24 *$ & $-.43 * *$ & -.05 & - & & & & \\
\hline 5. Withdrawal (mean of $\mathrm{K} \& 1 \mathrm{st}$ ) & .10 & -.02 & $.29 *$ & $-.32 *$ & - & & & \\
\hline 6. APRS (1st) & $-.27 *$ & -.14 & $-.31 *$ & $.57 * *$ & $-.53 * *$ & - & & \\
\hline 7. WJ-LW (1st) & $-.31 *$ & -.09 & .06 & $.37 * *$ & .08 & $.56 * *$ & - & \\
\hline 8. WJ-AP (1st) & -.11 & $-.52 * *$ & .06 & $.49 * *$ & -.21 & $.59 * *$ & $.43 * *$ & - \\
\hline \multicolumn{9}{|l|}{ Boys } \\
\hline 1. $D R D 2$ risk & - & & & & & & & \\
\hline 2. Race & $.23 *$ & - & & & & & & \\
\hline 3. Mother's $D R D 2$ risk & $.52 * *$ & $.28 * *$ & - & & & & & \\
\hline 4. Sensitive parenting (mean $6,12,24$, \& 36 months) & $-.28 * *$ & $-.34 * *$ & -.12 & - & & & & \\
\hline 5. Emotion regulation (mean of $\mathrm{K} \& 1 \mathrm{st}$ ) & $-.29 *$ & -.09 & -.12 & $.29 *$ & - & & & \\
\hline 6. APRS (1st) & -.11 & -.21 & -.19 & .31 & $.69 * * *$ & - & & \\
\hline 7. WJ-LW (1st) & $-.30 *$ & $-.30^{*}$ & $-.30 *$ & .23 & $.37 *$ & $.63 * *$ & - & \\
\hline 8. WJ-AP (1st) & $-.34 * *$ & $-.56 * *$ & $-.31 *$ & $-.44 * *$ & $.46^{* *}$ & $.62 * *$ & $.65 * *$ & 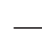 \\
\hline
\end{tabular}

Note: DRD4, dopamine receptor D4; K, kindergarten; 1st, first grade; APRS, Academic Achievement and Performance Rating Scale; WJ-LW, Woodcock-Johnson letter word subscale; WJ-AP, Woodcock-Johnson applied problems subscale; DRD2, dopamine receptor D2. $* p \leq .05 . * * p \leq .01 . * * * p \leq .001$. 
reflects the directionality of the hypotheses and considerations of power. Nevertheless, $t$ values are reported, and most substantively important paths are significant at nondirectional, two-tailed criteria. Table 4 reports the structural equation results for females for the three outcomes, the APRS, the WJ-AP, and the WJ-LW.

The fit statistics (absolute fit and adjusting for the model's complexity) for the APRS model suggest that the observed data correspond to the model well. The $\chi^{2}$ value is 25.3 with 20 degrees of freedom $(p=.19)$ and the standardized root mean square residual (SRMR) is 0.06, although the latter may be somewhat biased by the small sample size and low degrees of freedom. The $90 \%$ confidence interval for the root mean square error of approximation (90\% CI RMSEA) ranges from 0.00 to 0.12 , suggesting a good fit (MacCallum, Browne, \& Sugawara, 1996). Finally, the Tucker-Lewis index (TLI) is 0.97 , similarly suggesting an acceptable fit (e.g., Hu \& Bentler, 1999).

The path coefficients reveal several noteworthy findings. First, the child's $D R D 4$ polymorphism predicts parenting (standardized regression coefficient $=-.27, t=-2.49, p=.01$ ), controlling mother's DRD4 status (which is insignificant). This pattern of results is consistent with prior research and suggests an evocative correlation between the young girls' DRD4 status and the parenting behaviors that they evoke from their mothers. Race is also controlled and highly significant, suggesting that AA parents in this sample are showing less maternal sensitivity. Poverty status was entered into the model to examine whether the AA effect attenuated, but all of the model's parameters were essentially unchanged. Second, parenting is substantially, positively associated with the APRS (standardized regression coefficient $=0.43, t=2.94, p=.00$ ) and also with social withdrawal (standardized regression coefficient $=$ $-0.31, t=-2.26, p=.01$ ). The daughters of mothers who are sensitive and responsive and who show them positive regard are judged as more academically successful and productive by their teachers in the first grade, and also viewed as less withdrawn. Third, the APRS is in turn predicted by social withdrawal (standardized regression coefficient $=-0.39, t=$ $-3.32, p=.00)$.

The $R^{2}$ associated with the APRS is 0.47 ( $t=4.29, p=$ $.00)$, with significant total $(-0.28, t=-2.29, p=.01)$ and total indirect $(-0.15, t=-2.12, p=.02)$ effects originating from the child's $D R D 4$ status. An examination of the standard errors associated with the indirect effects provides evidence for mediation extending from child's $D R D 4$ to parenting to the APRS (standardized indirect effect $=-0.11, t=-1.89$, $p=.03$ ). Thus, the model suggests that DRD4 risk evokes less positive, sensitive parenting from the mother, which in turn is associated with teacher's assessment of academic success in the first grade. Although all of the individual paths extending from $D R D 4$ to parenting to social withdrawal to the APRS are significant, this more complex pathway is only marginally statistically significant (standardized indirect ef-

Table 4. Structural equation results (standardized estimates) DRD4 and school performance in the first grade for females

\begin{tabular}{lccc}
\hline \hline \multicolumn{1}{c}{ Outcome } & APRS & WJ-AP & WJ-LW \\
\hline Predicting parenting & & & \\
Daughter's DRD4 status & $-0.268^{*}$ & $-0.267^{*}$ & $-0.268^{*}$ \\
Mother's DRD4 status & 0.028 & 0.025 & 0.027 \\
Black & $-0.476^{* * *}$ & $-0.482^{* * *}$ & $-0.479^{* * *}$ \\
$R^{2}$ & 0.300 & 0.305 & 0.302 \\
Predicting social withdrawal & & & \\
Parenting & $-0.307^{*}$ & $-0.286^{*}$ & $-0.295^{*}$ \\
$R^{2}$ & 0.094 & 0.082 & 0.087 \\
Predicting outcome & & & \\
$\quad$ Daughter's $D R D 4$ status & -0.138 & 0.017 & $-0.309^{*}$ \\
Mother's $D R D 4$ status & -0.032 & 0.103 & 0.223 \\
Black & 0.074 & $-0.339^{* *}$ & 0.177 \\
Parenting & $0.425^{* *}$ & $0.364^{* *}$ & $-0.295^{*}$ \\
Social withdrawal & $-0.389^{* * *}$ & -0.187 & 0.101 \\
$R^{2}$ & 0.465 & 0.463 & 0.229 \\
$N$ & 81 & 81 & 81 \\
$\chi^{2}$ & 25.348 & 25.347 & 24.772 \\
$d f$ & 20 & 20 & 20 \\
$90 \%$ CI RMSEA & $0.000,0.118$ & $0.000,0.118$ & $0.000,0.116$ \\
TLI & 0.950 & 0.950 & 0.952 \\
SRMR & 0.064 & 0.059 & 0.060 \\
SBIC & -62.541 & -62.542 & -63.117 \\
\hline \hline
\end{tabular}

Note: APRS, Academic Achievement and Performance Rating Scale; WJ-AP, Woodcock-Johnson applied problems subscale; WJ-LW, Woodcock-Johnson letter word subscale; DRD4, dopamine receptor D4; CI RMSEA, confidence interval root mean square error of approximation; TLI, Tucker-Lewis index; SRMR, standardized root mean square residual; SBIC, Schwarz Bayesian information criterion.

$* p \leq .05 . * * \leq .01 . * * * x \leq .001$. 
fect $=-0.03, t=-1.53, p=.06)$. Still, given the low power to detect such a complex chain of mediation, these results warrant further study with larger samples.

The same model was reestimated, replacing the APRS with the WJ-AP. The model fit statistics for the WJ-AP suggest a good fit between the observed data and the model. Once again, results suggest an evocative gene correlation. The model's new feature is the WJ-AP, and the findings show that parenting significantly predicts it (standardized regression coefficient $=0.36, t=2.71, p=.00$ ), but social withdrawal does not. The $R^{2}$ for the WJ-AP is $0.46(t=$ $4.30, p=.00$ ), with significant total indirect effects (standardized $=-3.47, t=-1.95, p=.03$ ). An examination of the indirect paths again reveals that the girls' $D R D 4$ status is associated with the WJ-AP by way of parenting (standardized indirect effect $=-3.02, t=-1.80, p=.03$ ).

Finally, the model fits the data well for the WJ-LW, with a $\chi^{2}$ of 24.77 with 20 degrees of freedom $(p=.21)$ and an SMSR of 0.06 . The $90 \%$ CI RMSEA ranges from 0.00 to 0.11 , also suggesting a good fit, and the TLI is 0.95 . The results are quite comparable to those observed in the prediction of the APRS. It was not surprising that the results suggest an evocative gene-environment correlation (standardized regression coefficient $=-0.27, t=-2.49, p=.01$ ) and parenting predicts social withdrawal (standardized regression coefficient $=-0.29, t=-2.13, p=.02$ ). Of central interest, the model also reveals a significant path from parenting to the WJ-LW (standardized regression coefficient $=0.36, t=$ 2.30, $p=.01)$.

The $R^{2}$ for the WJ-LW is $0.23(t=2.34, p=.01)$, with significant total $(-9.67, t=-3.01, p=.00)$ and total indirect $(-2.14, t=-1.63, p=.05)$ effects extending from the girls' $D R D 4$ status. An examination of the specific indirect paths reveals that this mediation is extending from $D R D 4$ to parenting to the WJ-LW (standardized indirect effect $=-2.34, t=$ $-1.61, p=.05$ ), although this pattern is marginally significant.

\section{DRD2 and school performance: Males}

Table 5 reports the structural equation results for boys. The models are quite similar to those estimated for girls, except that they now include $D R D 2$ and emotion regulation. Turning to the APRS model, the fit statistics suggest that the observed data fit the model well. The $\chi^{2}$ is 22.70 with 20 degrees of freedom $(p=.30)$ and the SRMSR is 0.08 . The $90 \% \mathrm{CI}$ RMSEA ranges from 0.00 to 0.10 , suggesting a very good fit, and the TLI is 0.97 .

The pattern of path coefficients is not consistent with the meditational pattern observed among the girls. DRD2 status is associated with parenting (standardized regression coefficient $=-0.33, t=-3.01, p=.00)$, controlling for mother's DRD2 status, consistent with an evocative correlation. Parent-

Table 5. Structural equation results (standardized estimates) DRD2 and school performance in the first grade for males

\begin{tabular}{lccc}
\hline \multicolumn{1}{c}{ Outcome } & APRS & WJ-AP & WJ-LW \\
\hline Predicting parenting & & & \\
$\quad$ Son's DRD2 status & $-0.328^{* *}$ & $-0.328^{* * *}$ & $-0.328^{* *}$ \\
Mother's DRD2 status & $0.279^{*}$ & $0.279^{*}$ & $0.279^{*}$ \\
Black & $-0.506^{* * *}$ & $-0.507^{* * *}$ & $-0.507^{* * *}$ \\
$R^{2}$ & 0.341 & 0.341 & 0.342 \\
Predicting emotional regulation & & & \\
$\quad$ Parenting & $0.265^{*}$ & 0.209 & $0.263^{*}$ \\
$R^{2}$ & 0.070 & 0.044 & 0.069 \\
Predicting outcome & & & \\
Son's $D R D 2$ status & $0.403^{*}$ & 0.033 & 0.009 \\
Mother's $D R D 2$ status & -0.218 & -0.162 & -0.247 \\
Black & -0.119 & $-0.488 * * *$ & -0.210 \\
Parenting & 0.194 & 0.019 & -0.014 \\
Emotional regulation & $0.598^{* * *}$ & $0.409 * * *$ & $0.306^{*}$ \\
$R^{2}$ & 0.545 & 0.520 & 0.239 \\
$N$ & 85 & 85 & 85 \\
$\chi^{2}$ & 22.697 & 23.235 & 16.998 \\
$d f$ & 20 & 20 & 20 \\
RMSEA & $0.000-0.105$ & $0.000-0.107$ & $0.000-0.078$ \\
TLI & 0.972 & 0.969 & 1.034 \\
SRMR & 0.085 & 0.071 & 0.059 \\
SBIC & -66.156 & -65.618 & -71.855 \\
\hline \hline
\end{tabular}

Note: APRS, Academic Achievement and Performance Rating Scale; WJ-AP, Woodcock-Johnson applied problems subscale; WJ-LW, Woodcock-Johnson letter word subscale; DRD2, dopamine receptor D2; RMSEA, root mean square error of approximation; TLI, Tucker-Lewis index; SRMR, standardized root mean square residual; SBIC, Schwarz Bayesian information criterion.

$* p \leq .05 . * * p \leq .01 . * * * p \leq .001$. 
ing is not, however, significantly associated with the APRS. Thus, the path from $D R D 2$ to parenting to the APRS is not observed for the boys. The mother's DRD2 status is associated with parenting, although the direction of the effect is unexpected (standardized regression coefficient $=0.28, t=$ $2.44, p=.01$ ). Given that the bivariate correlation is insignificant, this pattern is unlikely to be substantively important. As with girls, AA mothers appear to engage in less sensitive parenting (standardized regression coefficient $=-0.51, t=$ $-5.72, p=.00)$. Once again, poverty status was entered into the model, but the parameters remained largely unchanged. Although the girls' meditational pattern is not observed among the boys, several interesting, unique patterns emerge. First, parenting predicts emotion regulation (standardized regression coefficient $=0.27, t=1.96, p=.03$ ), which in turn has a very substantial association with the APRS (standardized regression coefficient $=0.60, t=5.80, p=.00$ ). The indirect path extending from $D R D 2$ to parenting to emotion regulation to the APRS is marginally significant (standardized regression coefficient $=-0.05, t=-1.57, p=.06$ ). Given considerations of sample size (and thus power for such a complex meditational hypothesis) and the use of a one-tailed test, this pattern merits further study with a larger sample. The pattern suggests that young boys with $D R D 2$ risk evoke less positive, sensitive parenting, which leads to diminished emotion regulation and then lowered the APRS.

Second, controlling for these direct and indirect effects, $D R D 2$ has a direct effect on the APRS, although the direction of the effect is unexpected (standardized regression coefficient $=0.40, t=2.32, p=.01$ ). Given that the bivariate correlation is negative and insignificant, however, this finding is likely not substantively meaningful. Third, we reestimated the model to see whether there was a significant indirect effect extending from boys' $D R D 2$ status to emotion regulation to the APRS. No direct effect from $D R D 2$ to emotion regulation was observed, however. These results provide marginal support for the possibility that boys' $D R D 2$ status evokes parenting that is associated with the APRS by way of their emotion regulation.

In the model that predicts the WJ-AP scores, the results show that the model fits the data well, with a $\chi^{2}$ of 23.24 with 20 degrees of freedom $(p=.28)$ and a SRMR of 0.07 . The $90 \%$ CI RMSEA ranges from 0.00 to 0.11 and the TLI is 0.97 . The results once again reveal the evocative gene-environment correlation, although parenting is only marginally associated with emotion regulation in this specification (standardized regression coefficient $=0.21, t=1.54, p=.06$ ). Emotion regulation is strongly associated with the WJ-AP (standardized regression coefficient $=0.41, t=4.17, p=$ .00). Although the paths from $D R D 2$ to parenting, from parenting to emotion regulation, and from emotion regulation to the WJ-AP are all significant, the indirect effect associated with this complex meditational chain is not (standardized estimate $=-0.03, t=-1.32, p=.09$ ).

Finally, the WJ-LW results suggest a very good fit between the observed data and the model. The $\chi^{2}=17.0$ with
20 degrees of freedom $(p=.65)$ and SRMSR $=0.06$. The $90 \%$ CI RMSEA ranges from 0.00 to 0.08 , suggesting an excellent fit, and the TLI $=1.0$.

As was observed with the APRS, an evocative correlation is observed, but parenting is not associated with the WJ-LW. Parenting is, however, associated with emotional regulation, which is associated with the WJ-LW (standardized regression coefficient $=0.31, t=2.26, p=.01$ ). The $R^{2}$ for the WJ-LW is 0.24 , but no significant direct or indirect effects are observed extending from DRD2 to the WJ-LW. Thus, boys' $D R D 2$ risk status evokes less sensitive parenting, which in turn is associated with emotion regulation, which is significantly associated with the WJ-LW. The standard error associated with this indirect mediating pathway is insignificant, however.

\section{Discussion}

Are evocative gene-environment correlations involving young children and their mothers associated with school performance in the first grade? Our conceptual model (shown in Figure 1) suggests that genetic risk (defined in terms of dopamine receptors Types 2 and 4) evokes less sensitive parenting that in turn creates behavioral patterns that are less conducive to success in the classroom. The present study addressed this research question, drawing on rich longitudinal data from the Durham Child Health and Development Study. This data resource is strategically informative because of its extensive longitudinal assessments, which are a mix of observational data (with respect to parenting), teacher reports (with respect to adjustment and performance), and standardized tests of intellectual skills (involving reading and math). To our knowledge, no studies have examined connections between gene-parenting correlations and school performance, although there is ample theoretical support for such connections.

Nevertheless, these results should be regarded as exploratory and suggestive, primarily because they reflect a small sample and the findings have not been replicated. The small sample size increases the likelihood of false discoveries (particularly in the case of "novel findings" such as those reported here; Duncan \& Keller, 2011), decreases the power to detect meditational patterns, and does not allow for the inclusion of extensive controls in the models. In the present case, the results have not been replicated (which would otherwise mitigate the possibility of false discovery). However, data from the nationally representative Add Health sample suggest that DRD2 Taq1 1A (among boys) and DRD4 (among black girls) are associated with school continuation (Shanahan, Erickson, Vaisey, \& Smollen, 2007; and analyses available on request). Further, despite the lack of power, meditational chains are observed. The smaller sample size may be counterbalanced to some degree by the richness of longitudinal, observational assessments. However, this small sample does call for replication with larger samples. Moreover, although our measures of adjustment have excellent psychometric 
properties, they are based on teachers' reports, which are also the basis of the APRS. This overlap warrants caution when interpreting the results, which suggest a meditational pattern extending from teachers' reports of emotion regulation to the APRS (for boys, $r=.69$ ) and withdrawn behavior to the APRS (for girls, $r=-.53$ ). Whether it is because of these behaviors or actual performance in the classroom, or a combination of the two factors, teachers do view children with genetic risk and less sensitive parenting in less positive terms than children without that risk. Furthermore, in order to obtain a comprehensive assessment of children's academic performance and achievement, the current study examined both the teacher rating of academic success and standardized achievement tests, which do not reflect a common source.

\section{$r G E$, withdrawn behavior, and academic outcomes in girls}

The basic conceptual model informing our study was supported in several respects and suggests new avenues of research that explore family-school connections very early in life. For the girls, the findings suggest a significant meditational process by which young girls' $D R D 4$ status evokes less sensitive parenting from their mothers, which in turn is associated with the APRS, WJ-LW, and WJ-AP. In the APRS, there is weak evidence for a further meditational path extending from $D R D 4$ to parenting to social withdrawal to the APRS, which is noteworthy given the substantial power needed to reliably detect such a complex meditational chain. In any event, all of the association between the girls' DRD4 status and the APRS is mediated. Thus, the child-parent relationship between 6 and 36 months "carries over" to teachers' assessment of academic productivity, success, and behavioral control in the classroom and standardized intellectual measures in first grade.

Although previous studies have reported links between dopamine genes (e.g., DAT1, DRD2, DRD4) and academic achievement in middle and high school (Beaver, Vaughn, Wright, DeLisi, \& Howard) and educational attainment in late adolescence (Shanahan et al., 2008), none have looked at this relationship as early as kindergarten nor have they looked at early caregiving as a mediating link. Our examination of the path leading from dopaminergic genes to academic outcomes revealed a significant link for girls between DRD4 and parenting through 3 years of age, extending previous findings from this sample of an association between $D R D 4$ risk (L-DRD4) and less sensitive maternal caregiving observed through 1 year of age (Propper et al., 2007). Furthermore, we were able to rule out the possibility of a passive $r$ GE by including maternal genotype in the model, which was not associated with mothers' sensitive caregiving behavior. Although we did not examine the specific child behaviors that may elicit less sensitive caregiving from mothers, previous studies have found $D R D 4$ to be associated with more aggression, more sensation seeking, and more defiant behaviors in toddlers and young children (Benjamin et al., 2002;
Kirley et al., 2004; Schmidt et al., 2002), which could lead to a less positive parenting experiences and less sensitive responses to the child. It is especially troubling that this effect is found so early in life, because the positive and supportive interactions that occur between mother and child during this time are important for development of important regulatory strategies and processes. It is through these interactions with parents that emotion socialization occurs and self-regulatory skills necessary for social and academic success are developed (Cassidy, Parke, Butkovsky, \& Braungart, 1992; Denham, 1993; Denham, McKinley, Couchoud, \& Holt, 1990; Eisenberg \& Fabes, 1992; Parke, Burks, Carson, Neville, \& Boyum, 1994).

The subsequent significant path between parenting behavior and academic achievement, as assessed by each of three measures (APRS, WJ-AP, WJ-LW) is not surprising, given the multitude of findings predicting better academic outcomes from early elementary school through eighth grade for those children who experienced high-quality parent-child interactions (Denham, 1993; Estrada, Arsenio, Hess, \& Holloway, 1987; Morrison, Rimm-Kauffman, \& Pianta, 2003; Parke, Ornstein, Rieser, \& Zahn-Waxler, 1994; Pianta \& Harbers, 1996; Pianta et al., 1991; Welsh, Parke, Widaman, \& O'Neil, 2001). A recent longitudinal study of over 1,000 children entering school found that the strongest predictor of academic outcomes in the early school context was sensitive parenting (NICHD, 2002). Again, the early skills that are established prior to school entry may kick off a trajectory toward academic success that begins in the home and continues to grow as peers and teachers and classroom contexts build upon this foundation. Therefore, early parenting may have lasting effects on future achievement.

A novel contribution of the current study is the identification of a potential mediating path between early parenting (elicited by child genotype) and academic outcomes (as assessed by teacher report on APRS). Although we examined five subscales (related to internalizing and externalizing behaviors) of the CBCL-TRF as potential mediators, withdrawn behavior was the only one that significantly differed by DRD4 status, and only for girls. In other words, teachers evaluate girls with $D R D 4$ risk as more shy, less interactive, and lonelier compared to girls without $D R D 4$ risk. Although this link was not hypothesized, a recent study examined relations between DRD4 and each subscale of the CBCL (parent report) and found, as the present analyses did, that the only significant relationship was between $D R D 4$ and withdrawn behavior (Marino et al., 2004).

This mediational path was only found to predict teacher report of academic performance and not standardized achievement testing. Although the method of using teacher ratings of children's academic success has limitations, there are unique benefits to including assessments of academic success via teacher reports. These reports provide information about the student's academic behavior in the classroom, above and beyond scores on standardized tests. For example, teachers can report on behaviors that support productive and high-quality 
work (i.e., the ability to independently attend to and complete assignments, follow instructions, independently grasp new information, and complete classroom assignments accurately). Therefore, girls' withdrawn behavior is perceived by teachers to influence their academic behaviors in a negative direction, when, in actuality, their achievement scores do not appear to be affected by this behavior. This pattern has important implications for the way in which the teacher-child relationship may develop and affect future performance; a teacher who does not believe a child is productive, bright, or competent may fail to provide him or her with a stimulating or challenging learning environment, leading to diminished self-esteem, performance, and motivation in the classroom that may carry forward to future grades and academic problems.

\section{$r G E$, emotion regulation, and academic outcomes in boys}

The results for boys are not consistent with the path observed for the girls. There is weak evidence for a more complex pathway, however, extending from $D R D 2$ through parenting and emotional regulation to school performance and achievement. This pattern suggests that boys with $D R D 2$ risk $\left(\mathrm{A}_{1}^{+}\right)$evoke less sensitive parenting, which is associated with diminished emotion regulation (e.g., more prone to frustration and less emotional control), which is (a) associated with teachers' reports on the APRS (that these boys are less productive, have lower quality work, and are less able to control behavior in first grade), (b) associated with the WJ-III reading subscale (WJ-LW), and (c) marginally associated with the WJ-III math subscale (WJ-AP). The latter two relationships reflect significant pathways but not significant indirect effects.

Similar to the finding of an evocative effect of L-DRD4 on less sensitive parenting as described above, we found an $r \mathrm{GE}$ correlation for boys between the risk allele of $D R D 2\left(\mathrm{~A}_{1}^{+}\right)$and less maternal sensitivity through 3 years of age that extends previous findings from the current sample that examined parenting through the first year of life (Mills-Koonce et al, 2007). Unlike the findings for $D R D 4$, in this case maternal caregiving was significantly associated with mothers' genotype (indicating a potential passive $r \mathrm{GE}$ ); however, after controlling for this in the model child genotype was still a significant predictor of maternal sensitivity. Again, we did not examine the specific child behaviors that elicited less sensitivity from mothers in the current analyses, although previous studies have linked $D R D 2$ to difficult behaviors and less regulation in infants, children, and adolescents (e.g., Comings et al., 1996; Lu, Lee, Ko, \& Lin, 2001; McGue et al., 1997; Propper et al., 2008; Wiers et al., 1994).

Unlike the results described above for girls, the link between maternal sensitivity and academic achievement was fully mediated by ratings of emotion regulation for boys. Emotion regulation has also been found to be a strong predictor of performance in the classroom in older children and adolescence, and this association has been observed in studies of preschool and kindergarten children as well (Graziano et al., 2007; Howse et al., 2003).
Several possible mechanisms have been posited for how emotion regulation may influence cognitive performance. First, the ability to control emotional arousal allows children to engage in more challenging tasks, which subsequently provide opportunities for using and practicing executive function skills (Calkins \& Dedmon, 2000). Second, it is hard to teach disruptive kids, so these children may get less feedback and instruction in the classroom, and their overall experience may be less rewarding, which may lead to lower motivation or interest in achievement (Raver, 2004). Third, if intense emotions are not regulated appropriately and the child reacts to his or her emotional state in less effective ways (i.e., acting out in response to frustration, vigilance in response to anxiety), the resources and energy expended may interfere with the those necessary for the higher order cognitive demands of the classroom setting (Blair, 2002). Alternatively, when arousal is maintained at optimal levels, through regulatory processes, and affective experience does not compete with or interfere with cognitive demands, children are then able to utilize higher order processes important for problem solving (Campos \& Barrett, 1984; Carver \& Scheier, 2000). Therefore, the importance of emotion regulation in the classroom for academic success is well established.

\section{Future directions}

Given the exploratory nature of the analyses, further study of the conceptual model is needed with larger samples. Beyond this need for replication, several refinements may also be probative. First, $D R D 4$ and $D R D 2$ evoke less sensitive parenting, but the data do not allow us to examine the types of behaviors, on the part of the children, that elicit these reactions from mothers. Moreover, little is known about the mothers themselves and possible sources of resilience that promote sensitive parenting for children with genetic risk. Second, although animal models and other sources of evidence suggest that $D R D 4$ and $D R D 2$ have functional significance that bolster the plausibility of the models and findings, the research design does not warrant any definite causal statements. Other designs, with greater internal validity, are needed in the study of the conceptual model. Third, our genetic candidates and forms of psychosocial adjustment could be expanded considerably. For example, monoamine oxidase A is very likely related to aggression or antisocial symptoms. Perhaps monoamine oxidase A also evokes less sensitive parenting, which in turn is associated with antisocial acts and lowered school performance. Epistatic patterns are also plausible. For example, consistent with the differential susceptibility hypothesis, perhaps the present results would be stronger for carriers of s/s alleles of the serotonin transporter linked polymorphic region gene. Some evidence suggests that the $D R D 4$ polymorphism studied here is actually a susceptibility gene (e.g., Bakermans-Kranenburg \& van IJzendoorn, 2011), in which case Figure 1 would be tested as a moderational model. In any event, the available data provide a limited empirical examination of the conceptual model shown in 
Figure 1, with many other genes and indicators of adjustment likely contributing to school performance.

Despite these limitations, however, this is the first study suggesting that an evocative gene-environment correlation involving parenting has repercussions beyond the family, possibly influencing the first moments of the academic tra- jectory. Although the results call for replication and refinement, our findings provide a first step toward understanding how the role of genetics in family functioning, and the child as an organizer of parenting behavior, may influence behavior in the classroom context and future academic achievement.

\section{References}

Achenbach, T. M., \& Rescorla, L. A. (2001). Manual for the ASEBA SchoolAge Forms \& Profiles. Burlington, VT: University of Vermont, Research Center for Children, Youth, \& Families.

Anchordoquy, H. C., McGeary, C., Liu, L., Krauter, K. S., \& Smolen, A. (2003). Genotyping of three candidate genes after whole-genome preamplification of DNA collected from buccal cells. Behavior Genetics, 33, 73-78.

Asgahari, V., Schoots, O., van Kats, S., O’Hara, K., Jovanovic, V., Guan, H. C., et al. (1994). Dopamine D4 receptor repeat: Analysis of different native and mutant forms. Molecular Pharmacology, 46, 364-373.

Atkinson, L., Chisholm, V. C., Scott, B., Goldberg, S., Vaughn, B. E., Blackwell, J., et al. (1999). Maternal sensitivity, child functional level, and attachment in Down syndrome. Monographs of the Society for Research in Child Development, 64, 45-66.

Bakermans-Kranenburg, M. J., \& van IJzendoorn, M. H. (2011). Differential susceptibility to rearing environment depending on dopamine-related genes: New evidence and a meta-analysis. Development and Psychopathology, 23, 39-52.

Bardone, A .M., Moffitt, T. E., Caspi, A., Dickson, N., \& Silva, P. A. (1996). Adult mental health and social outcomes of adolescent girls with depression and conduct disorder. Development and Psychopathology, 8, 811-829.

Beaver, M., Vaughn, M. G., Wright, J. P., DeLisi, M., \& Howard, M. O. (2010). Three dopaminergic polymorphisms are associated with academic achievement in middle and high school. Intelligence, 38, 596-604.

Belsky, J. (1984). The determinants of parenting: A process model. Child Development, 55, 83-96.

Benjamin, J., Ebstein, R. P., \& Belmaker, R. H. (2002). Molecular genetics and the human personality. Washington, DC: American Psychiatric Publishing.

Benjamin, J., Li, L., Patterson, C., Greenberg, B. D., Murphy, D. L., \& Hamer, D. H. (1996). Population and familial association between the D4 dopamine receptor gene and measures of novelty seeking. Nature Genetics, 12, 81-84.

Bérubé, R. L., \& Achenbach, T. M. (2001). Bibliography of published studies using the Achenbach System of Empirically Based Assessment (ASEBA). Burlington, VT: University of Vermont, Research Center for Children, Youth, \& Families.

Birkas, E., Lakatos, K., Nemoda, Z., Ney, K., Toth, I., Novak, A., et al. (2005). Effects of the D4 dopamine receptor gene variation on behavior problems at 6 years of age. Neuropsychopharmacologia Hungarica, 7, 125-131.

Blair, C. (2002). School readiness: Integrating cognition and emotion in a neurobiological conceptualization of child functioning at school entry. American Psychologist, 57, 111-127.

Blair, C., Granger, D., Willoughby, M., Kivlighan, K., \& The Family Life Project Investigators. (2006). Maternal sensitivity is related to hypothalamic-pituitary-adrenal axis stress reactivity and regulation in response to emotion challenge in 6-month-old infants. Annals of the New York Academy of Sciences, 1094, 263-267.

Blair, C., \& Peters, R. (2003). Physiological and neurocognitive correlates of adaptive behavior in preschool among children in Head Start. Developmental Neuropsychology, 24, 479-497.

Blum, K., Noble, E. P., Sheridan, P. J., Finley, O., Montgomery, A., Ritchie, T., et al. (1991). Association of the A1 allele of the D2 dopamine receptor gene with severe alcoholism. Alcohol, 8, 409-416.

Booth, C. L., Rose-Krasnor, L., McKinnon, J., \& Rubin, K. H. (1994). Predicting social adjustment in middle childhood: The role of preschool attachment security and maternal style. Social Development, 3, 189-204.

Bramlett, R. K., Rowell, R., \& Mandenberg, K. (2000). Predicting first-grade achievement from kindergarten screening measures: A comparison of child and family predictors. Research in the Schools, 7, 1-9.

Brumback, R. A., Dietz-Schmidt, S. G., \& Weinberg, W. A. (1977). Depression in children referred to an educational diagnostic center: Diagnosis and treatment and analysis of criteria and literature review. Disturbances of the Nervous System, 38, 529-535.

Bull, R., \& Scherif, G. (2001). Executive functioning as a predictor of children's mathematics ability: Inhibition, switching, and working memory. Developmental Neuropsychology, 19, 273-293.

Calkins, S. D., \& Dedmon, S. E. (2000). Physiological and behavioral regulation in two-year-old children with aggressive/destructive behavio problems. Journal of Abnormal Child Psychology, 28, 103-118.

Calkins, S. D., Smith, C. L., Gill, K., \& Johnson, M. C. (1998). Maternal interactive style across contexts: Relations to emotional, behavioral, and physiological regulation during toddlerhood. Social Development, 7, 350-369.

Campos, J. J., \& Barrett, K. (1984). Toward a new understanding of emotions and their development. In C. E. Izard, J. Kagan, R. B. Zajonc, C. E. Izard, J. Kagan, \& R. B. Zajonc (Eds.), Emotions, cognition, and behavior (pp. 229-263). New York: Cambridge University Press.

Carver, C. S., \& Scheier, M. F. (2000). Scaling back goals and recalibration of the affect system are processes in normal adaptive self-regulation: Understanding "response shift" phenomena. Social Science \& Medicine, 50, 1715-1722.

Cassidy, J., Parke, R. D., Butkovsky, L., \& Braungart, J. M. (1992). Familypeer connections: The roles of emotional expressiveness within the family and children's understanding of emotions. Child Development, 63, 603-618.

Chen, X., Rubin, K. H., \& Li, Z. (1995). Social functioning and adjustment in Chinese children: A longitudinal study. Developmental Psychology, 31, 531-539.

Chen, X., Rubin, K. H., \& Li, D. (1997). Relation between academic achievement and social adjustment: Evidence from Chinese children. Develop mental Psychology, 33, 518-525.

Cicchetti, D., \& Toth, S. L. (1995). A developmental psychopathology perspective on child abuse and neglect. Journal of the American Academy of Child \& Adolescent Psychiatry, 34, 541-565.

Cloninger, C. (1987). A systematic method for clinical description and classification of personality variants. Archives of General Psychiatry, 44, 573-588.

Cloninger, C. R., Adolfsson, R., \& Svrakic, N. M. (1996). Mapping genes for human personality. Nature Genetics, 12, 3-4.

Comings, D. E., Rosenthal, R. J., Lesieur, H. R., Rugle, L. J., Muhleman, D., Chiu, C., et al. (1996). A study of the dopamine D2 receptor gene in pathological gambling. Pharmacogenetics, 6, 223-234.

Cox, M. J., Owen, M. T., Henderson, V. K., \& Margand, N. A. (1992). Antecedents of infant-father and infant-mother attachment. Developmental Psychology, 28, 474-483.

Cox, M. J., \& Paley, B. (2003). Understanding families as systems. Current Directions in Psychological Science, 12, 193-196.

Crockenberg, S. B. (1981). Infant irritability, mother responsiveness, and social support influences on the security of infant-mother attachment. Child Development, 52, 857-865.

Denham, S. A. (1993). Maternal emotional responsiveness and toddler's social-emotional functioning. Journal of Child Psychology, 34, 715-728.

Denham, S. A., McKinley, M., Couchoud, E. A., \& Holt, R. (1990). Emotional and behavioral predictors of preschool peer ratings. Child Development, 61, 1145-1152.

Derryberry, D., \& Rothbart, M. K. (1984). Emotion, attention, and temperament. In C. E. Izard, J. Kagan, \& R. B. Zajonc (Eds.), Emotions, cognition, and behavior (pp. 132-166). Cambridge: Cambridge University Press.

Dick, D. M., Rose, R. J., \& Kaprio, J. (2006). The next challenge for psychiatric genetics: Characterizing the risk associated with identified genes. Annals of Clinical Psychiatry, 18, 223-231.

DiPerna, J., Lei, P., \& Reid, E. E. (2007). Kindergarten predictors of mathematical growth in the primary grades: An investigation using the Early 
Childhood Longitudinal Study - kindergarten cohort. Journal of Educational Psychology, 99, 369-379.

Dobbs, J., Doctoroff, G. L., Fisher, P. H., \& Arnold, D. H. (2006). The association between preschool children's socioemotional functioning and their mathematical skills. Journal of Applied Developmental Psychology, 27, 97-108.

Dodge, K. A., \& Pettit, G. S. (2003). A biopsychosocial model of the development of chronic conduct problems in adolescence. Developmental Psychology, 39, 349-371.

Duncan, L. E., \& Keller, M. C. (2011). A critical review of the first 10 years of candidate gene-by-environment interaction research in psychiatry. American Journal of Psychiatry, 168, 1041-1049.

DuPaul, G. J., Rapport, M. D., \& Perriello, L. M. (1991). Teacher ratings of academic skills: The development of the Academic Performance Rating Scale. School Psychology Review, 20, 284-300.

Ebstein, R. P., Levine, J., Geller, V., Auerbach, J., Gritsenko, I., \& Belmaker, R. H. (1998). Dopamine D4 receptor and serotonin transporter promoter in the determination of neonatal temperament. Molecular Psychiatry, 3, 238-246.

Ebstein, R. P., Nemanov, L., Klotz, I., Gritsenko, I., \& Belmaker, R. H. (1997). Additional evidence for an association between the dopamine D4 receptor (DRD4) exon III polymorphism and the human personality trait of novelty seeking. Molecular Psychiatry, 2, 472-477.

Edelsohn, G., Ialongo, N., Werthamer-Larsson, L., Crockett, L., \& Kellam, S. (1992). Self-reported depressive symptoms in first-grade children: Developmentally transient phenomena? Journal of the American Academy of Child \& Adolescent Psychiatry, 31, 282-290.

Eisenberg, D. T., Mackillop, J., Modi, M., Beauchemin, J., Dang, D., Lisman, S. A., et al. (2007). Examining impulsivity as an endophenotype using a behavioral approach: A DRD2 TaqI A and DRD4 48-bp VNTR association study. Behavioral and Brain Functions, 3, Article 2. doi:10.1186/1744-9081-3-2

Eisenberg, N., \& Fabes, R. A. (1992). Emotion, regulation, and the development of social competence. In M. S. Clark (Ed.), Review of personality and social psychology: Vol. 14. Emotion and social behavior (pp. 119-150). Newbury Park, CA: Sage.

Entwisle, D. R., Alexander, K. L., \& Olson, L. S. (2005). First grade and educational attainment by age 22: A new story. American Journal of Sociology, 110, 1458-1502.

Estrada, P., Arsenio, W. F., Hess, R. D., \& Holloway, S. D. (1987). Affective quality of the mother-child relationship: Longitudinal consequences for children's school-relevant cognitive functioning. Developmental Psychology, 23, 210-215.

Fleming, C. B., Harachi, T. W., Cortes, R. C., Abbott, R. D., \& Catalano, R. F. (2004). Level and change in reading scores and attention problems during elementary school as predictors of problem behavior in middle school. Journal of Emotional and Behavioral Disorders, 12, 130-144.

Frank, M. J., \& Hutchison, K. (2009). Genetic contributions to avoidancebased decisions: Striatal D2 receptor polymorphisms. Neuroscience, $164,131-140$.

Frank, M. J., Moustafa, A. A., Haughey, H., Curran, T., \& Hutchison, K. (2007). Genetic triple dissociation reveals multiple roles for dopamine in reinforcement learning. Proceedings of the National Academy of Sciences, 104, 16311-16316.

Fuchs, L. S., Fuchs, D., Prentice, K., Burch, M., Hamlett, C. L., Owen, R., et al. (2003). Enhancing third-grade student mathematical problem solving with self-regulated learning strategies. Journal of Educational Psychology, 95, 306-315.

George, S. R., Cheng, R., Nguyen, T., Israel, Y., \& O’Dowd, B. F. (1993). Polymorphisms of the D4 dopamine receptor alleles in chronic alcoholism. Biochemical and Biophysical Research Communications, 196, $107-114$.

Gray, J. (1982). The neuropsychology of anxiety. New York: Oxford University Press.

Graziano, P. A., Reavis, R. D., Keane, S. P., \& Calkins, S. D. (2007). The role of emotion regulation in children's early academic success. Journal of School Psychology, 45, 3-19.

Griffin, E. A., \& Morrison, F. J. (1997). The unique contribution of home literacy environment to differences in early literacy skills. Early Child Development and Care, 127-128, 233-243.

Grigorenko, E. L., Geiser, C., Slobodskaya, H. R., \& Francis, D. J. (2010). Cross-informant symptoms from CBCL, TRF, and YSR: Trait and method variance in a normative sample of Russian youths. Psychological Assessment, 22, 893-911.
Haley, D. W., \& Stansbury, K. (2003). Infant stress and parent responsiveness: Regulation of physiology and behavior during still-face and reunion. Child Development, 74, 1534-1546.

Hammen, C., \& Rudolph, K. D. (1996). Childhood depression. New York: Guilford Press.

Hill, A. L., Degnan, K. A., Calkins, S. D., \& Keane, S. P. (2006). Profiles of externalizing behavior problems for boys and girls across preschool: The roles of emotion regulation and inattention. Developmental Psychology, 42, 913-928.

Hinshaw, S. P. (1992). Externalizing behavior problems and academic underachievement in childhood and adolescence: Causal relationships and underlying mechanisms. Psychological Bulletin, 111, 127-155.

Hodges, K., \& Plow, J. (1990). Intellectual ability and achievement in psychiatrically hospitalized children with conduct, anxiety, and affective disorders. Journal of Consulting and Clinical Psychology, 58, 589-595.

Howse, R. B., Calkins, S. D., Anastopoulos, A. D., Keane, S. P., \& Shelton, T. L. (2003). Regulatory contributors to children's kindergarten achievement. Early Education and Development, 14, 101-119.

Hu, L., \& Bentler, P. M. (1999). Cutoff criteria for fit indexes in covariance structure analysis: Conventional criteria versus new alternatives. Structural Equation Modeling, 6, 1-55.

Ialongo, N., Edelsohn, G., Werthamer-Larsson, L., Crockett, L., \& Kellam, S. (1995). The significance of self-reported anxious symptoms of first-grade children: Prediction to anxious symptoms and adaptive functioning in fifth grade. Journal of Child Psychology and Psychiatry, 36, 427-1427.

Jaffee, S. R., \& Price, T. S. (2007). Gene-environment correlations: A review of the evidence and implications for prevention of mental illness. Molecular Psychiatry, 12, 432-442.

Keogh, B. K. (1992). Temperament and teachers' views of teachability. In W. Carey \& S. McDevitt (Eds.), Prevention and early intervention: Individual differences as risk factors for the mental health of children (pp. 246254). New York: Bruner/Mazel.

Kerckhoff, A. C. (2007). Diverging pathways: Social structure and career deflections. New York: Cambridge University Press.

Kirley, A., Lowe, N., Mullins, C., McCarron, M., Daly, G., Waldman, I., et al. (2004). Phenotype studies of the DRD4 gene polymorphisms in ADHD: Association with oppositional defiant disorder and positive family history. American Journal of Medical Genetics: Neuropsychiatric Genetics, 131B, 38-42.

Kochanska, G. (2001). Emotional development in children with different attachment histories: The first three years. Child Development, 72, 474-490.

Ladd, G. W., Birch, S. H., \& Buhs, E. S. (1999). Children's social and scholastic lives in kindergarten: Related spheres of influence? Child Development, 70, 1373-1400.

LaHoste, G. J., Swanson, J. M., Wigal, S. B., Glabe, C., Wigal, T., King, N., et al. (1996). Dopamine D4 receptor gene polymorphism is associated with attention-deficit/hyperactivity disorder. Molecular Psychiatry, 1, 83-84.

Lawford, B. R., Young, R. M., Noble, E. P., Sargent, J., Rowell, J., Shadforth, S., et al. (2000). The D2 dopamine receptor A(1) allele and opioid dependence: Association with heroin use and response to methadone treatment. American Journal of Medical Genetics, 96, 592-598.

Leadbeater, B. J., Bishop, S. J., \& Raver, C. C. (1996). Quality of mothertoddler interactions, maternal depressive symptoms, and behavior problems in preschoolers of adolescent mothers. Developmental Psychology, $32,280-288$.

Lin, H., Lawrence, F. R., \& Gorrell, J. (2003). Kindergarten teachers' views of children's readiness for school. Early Childhood Research Quarterly, $18,225-237$.

Lu, R. B., Lee, J. F., Ko, H. C., \& Lin, W. W. (2001). Dopamine D2 receptor gene (DRD2) is associated with alcoholism with conduct disorder. Alcoholism: Clinical and Experimental Research, 25, 177-184.

Lucht, M., Barnow, S., Schroeder, W., Grabe, H. J., Finckh, U., John, U., et al. (2006). Negative perceived paternal parenting is associated with dopamine D2 receptor exon 8 and GABA(A) alpha 6 receptor variants: An explorative study. American Journal of Medical Genetics: Part B Neuropsychiatric Genetics, 141B, 167-172.

MacCallum, R. C., Browne, M. W., \& Sugawara, H. M. (1996). Power analysis and determination of sample size for covariance structure modeling. Psychological Methods, 1, 130-149.

Maguin, E., \& Loeber, R. (1996). Academic performance and delinquency. Crime and Justice, 20, 145-264.

Marino, C., Vanzin, L., Giordo, R., Frigerio, A., Lorussa, M. L., Nobile, M., et al. (2011). An assessment of transmission disequilibrium between 
quantitative measures of childhood problem behaviors and DRD2/TaqI and DRD4/48 bp-repeat polymorphisms. Behavior Genetics, 34, 495502.

Martin, R. P., Nagle, R., \& Paget, K. (1983). Relationships between temperament and classroom behavior, teacher attitudes, and academic achievement. Journal of Psychoeducational Assessment, 1, 377-386.

Martin-Soelch, J., Szczepanik, A., Nugent, K., Barhaghi, D., Rallis, P., Herscovitch, R. E., et al. (2011). Lateralization and gender differences in the dopaminergic response to unpredictable reward in the human ventral striatum. European Journal of Neuroscience, 33, 1706-1715.

Masten, A. S., Roisman, G. I., Long, J. D., Burt, K. B., Obradović, J., Riley, J. R., et al. (2005). Developmental cascades: Linking academic achievement, externalizing and internalizing symptoms over 20 years. Developmental Psychology, 41, 733-746.

Mather, N., \& Woodcock, R. W. (2001). Woodcock Johnson III Tests of Achievement: Examiner's manual. Itasca, IL: Riverside.

McClelland, M. M., Cameron, C. E., Connor, C. M., Farris, C. L., Jewkes, A. M., \& Morrison, F. J. (2007). Links between behavioral regulation and preschoolers' literacy, vocabulary, and math skills. Developmental Psychology, 43, 447-459.

McGue, M., Slutske, W., Taylor, J., \& Iacono, W. G. (1997). Personality and substance use disorders: I. Effects of gender and alcoholism subtype. Alcoholism: Clinical and Experimental Research, 21, 513-520.

Mills-Koonce, W., Gariépy, J., Propper, C., Sutton, K., Calkins, S., Moore, G., et al. (2007). Infant and parent factors associated with early maternal sensitivity: A caregiver-attachment systems approach. Infant Behavior and Development, 30, 114-126.

Mills-Koonce, W. R., Propper, C., Gariépy, J. L., Blair, C., Garrett-Peters, P., \& Cox, M. J. (2008). Bidirectional genetic and environmental influence on mother and child behavior: The family system as the unity of analyses. Development and Psychopathology, 19, 1073-1087.

Miyake, H., Nagashima, K., Onigata, K., Nagashima, T., Takano, Y., \& Morikawa, A. (1999). Allelic variations of the D2 dopamine receptor gene in children with idiopathic short stature. Journal of Human Genetics, 44, 26-29.

Moore, G. A., \& Calkins, S. D. (2004). Infants' vagal regulation in the stillface paradigm is related to dyadic coordination of mother-infant interaction. Developmental Psychology, 40, 1068-1080.

Moore, G. A., Hill-Soderlund, A. L., Propper, C. B., Calkins, S. D., MillsKoonce, W., \& Cox, M. J. (2009). Mother-infant vagal regulation in the face-to-face still-face paradigm is moderated by maternal sensitivity. Child Development, 80, 209-223.

Morrison, E., Rimm-Kauffman, S., \& Pianta, R. C. (2003). A longitudinal study of mother-child interactions at school entry and social and academic outcomes in middle school. Journal of School Psychology, 41, 185-200.

Munro, C. A., McCaul, M. E., Oswald, L. M., Wong, D. F., Zhou, Y., Brasic, J., et al. (2006). Striatal dopamine release and family history of alcoholism. Alcoholism: Clinical and Experimental Research, 30, 1143-1151.

Neville, M. J., Johnstone, E. C., \& Walton, R. T. (2004). Identification and characterization of ANKK1: A novel kinase gene closely linked to DRD2 on chromosome band 11q23.1. Human Mutation, 23, 540-545.

Newman, R. S. (1998). Students' help seeking during problem solving: Influences of personal and contextual achievement goals. Journal of Educational Psychology, 9, 644-658.

NICHD Early Child Care Research Network. (2002). Early child care and children's development prior to school entry: Results from the NICHD Study of Early Child Care. American Education Research Journal, 39, 133-164.

Noble, E. P. (2003). D2 dopamine receptor gene in psychiatric and neurologic disorders and its phenotypes. American Journal of Medical Genetics Part B: Neuropsychiatric Genetics, 116B, 103-125.

Noble, E. P., Ozkaragoz, T. Z., Ritchie, T. L., Zhang, X., Belin, T. R., \& Sparkes, R. S. (1998). D2 and D4 dopamine receptor polymorphisms and personality. American Journal of Medical Genetics: Neuropsychiatric Genetics, 81, 257-267.

Noble, E. P., Syndulko, K., Fitch, R. J., Ritchie, T., Bohlman, M. C., Guth, P., et al. (1994). D2 dopamine receptor Taq1A alleles in medically ill alcoholic and nonalcoholic patients. Alcohol, 29, 729-744.

Normandeau, S., \& Guay, F. (1998). Preschool behavior and first-grade school achievement: The mediational role of cognitive self-control. Journal of Educational Psychology, 90, 111-121.

Ollendick, T. H., Weist, M. D., Borden, M., \& Greene, R. W. (1992). Sociometric status and academic, behavioral, and psychological adjustment: A five-year longitudinal study. Journal of Consulting and Clinical Psychology, 60, 80-87.

Olson, S. L., Bates, J. E., Sandy, J. M., \& Lanthier, R. (2000). Early developmental precursors of externalizing behavior in middle childhood and adolescence. Journal of Abnormal Child Psychology, 28, 119-133.

Palinsin, H. A. (1986). Preschool temperament and performance on achievement tests. Developmental Psychology, 22, 766-770.

Panskepp, J. (1986). The neurochemistry of behavior. Annual Review of Psychology, 37, 77-107.

Parke, R., Burks, V., Carson, J., Neville, B., \& Boyum, L. (1994). Familypeer relationships: A tripartite model. In R. D. Parke \& S. G. Kellam (Eds.), Exploring family relationships with other social contexts (pp. 115-145). New York: Taylor \& Francis.

Parke, R. D., Ornstein, P. A., Rieser, J. J., \& Zahn-Waxler, C. (1994). A century of developmental psychology. Washington, DC: American Psychological Association.

Pérez de Castro, I., Ibáñez, A., Torres, P., Sáiz-Ruiz, J., \& Fernández-Piqueras, J. (1997). Genetic association study between pathological gambling and a functional DNA polymorphism at the D4 receptor gene. Pharmacogenetics, 7, 345-348.

Pianta, R. C., \& Harbers, K. L. (1996). Observing mother and child behavior in a problem-solving situation at school entry: Relations with academic achievement. Journal of School Psychology, 34, 307-322.

Pianta, R. C., Smith, N., \& Reeve, R. E. (1991). Observing mother and child behavior in a problem-solving situation at school entry: Relations with classroom adjustment. School Psychology Quarterly, 6, 1-15.

Plomin, R., DeFries, J., \& Loehlin, J. (1977). Genotype-environment interaction and correlation in the analysis of human behavior. Psychological Bulletin, 84, 309-322.

Plomin, R., \& Rutter, M. (1998). Child development, molecular genetics, and what to do with genes once they are found. Child Development, 69, 12231242.

Pohjalainen, T., Rinne, J. O., Nagren, K., Lehikoinen, P., Anttila, K., Syvalahti, E. K. G., et al. (1998). The A1 allele of the human D2 dopamine receptor gene predicts low $\mathrm{D} 2$ receptor availability in healthy volunteers. Molecular Psychiatry, 3, 256-260.

Propper, C., \& Moore, G. A. (2006). The influence of parenting on infant emotionality: A multilevel psychobiological perspective. Developmental Review, 26, 427-460.

Propper, C., Moore, G. A, Mills-Koonce, W. R., Calkins, S. D., Carbone, M. A., \& Cox, M. (2008). Gene-environment contributions to the development of infant vagal reactivity: The interaction of dopamine and maternal sensitivity. Child Development, 79, 1377-1394.

Propper, C. C., Willoughby, M. M., Halpern, C. T., Carbone, M. A., \& Cox M. M. (2007). Parenting quality, DRD4, and the prediction of externalizing and internalizing behaviors in early childhood. Developmental Psychobiology, 49, 619-632.

Raver, C. (2004). Placing emotional self-regulation in sociocultural and socioeconomic contexts. Child Development, 75, 346-353.

Rimm-Kaufman, S. E., Pianta, R. C., \& Cox, M. J. (2000). Teachers' judgments of problems in the transition to kindergarten. Early Childhood Research Quarterly, 15, 147-166.

Risi, S., Gerhardstein, R., \& Kistner, J. (2003). Children's classroom peer relationships and subsequent educational outcomes. Journal of Clinical \& Adolescent Psychology, 32, 351-361.

Rutter, M. (2006). Implications of resilience concepts for scientific understanding. Annals of the New York Academy of Sciences, 1094, 1-12.

Rutter, M., Moffitt, T. E., \& Caspi, A. (2006). Gene-environment interplay and psychopathology: Multiple varieties but real effects. Journal of Child Psychology and Psychiatry, 47, 226-261.

Rutter, M., \& Silberg, J. (2002). Gene-environment interplay in relation to emotional and behavioral disturbance. Annual Review of Psychology, $53,463-490$.

Scarr, S., \& McCartney, K. (1983). How people make their own environments: A theory of genotype $\rightarrow$ environment effects. Child Development $54,424-435$.

Schmidt, L. A., Fox, N. A., Rubin, K. H., Hu, S., \& Hamer, D. H. (2002). Molecular genetics of shyness and aggression in preschoolers. Personality and Individual Differences, 33, 227-238.

Shamir-Essakow, G., Ungerer, J. A., Rapee, R. M., \& Safier, R. (2004). Caregiving representations of mothers of behaviorally inhibited and uninhibited preschool children. Developmental Psychology, 40, 899-910.

Shanahan, M. J., Erickson, L. D., Vaisey, S., \& Smollen, A. (2007). Helping relationships and genetic propensities: A combinatoric study of $D R D 2$, 
mentoring, and educational continuation. Twin Research and Human Genetics, 10, 285.

Shanahan, M. J., Vaisey, S., Erickson, L. D., \& Smolen, A. (2008). Environmental contingencies and genetic predispositions: Social capital, educational continuation, and a dopamine receptor polymorphism. American Journal of Sociology, 114, 260-286.

Shaw, D. S., Owens, E. B., Giovannelli, J., \& Winslow, E. (2001). Infant and toddler pathways leading to early externalizing disorders. Journal of the American Academy of Child \& Adolescent Psychiatry, 40, 36-43.

Shields, A. M., \& Cicchetti, D. (1997). Emotion regulation in school-age children: The development of a new criterion Q-sort scale. Developmental Psychology, 33, 906-916.

Shields, A., \& Cicchetti, D. (1998). Reactive aggression among maltreated children: The contributions of attention and emotion dysregulation. Journal of Clinical Child Psychology, 27, 381-395.

Shields, A. M., \& Cicchetti, D. (2001). Parental maltreatment and emotion dysregulation as risk factors for bullying and victimization in middle childhood. Journal of Clinical Child \& Adolescent Psychology, 30, 349-363.

Shields, P., Lerman, C., Audrain, J., Main, D., Boyd, N., \& Caporaso, N. (1998). Dopamine D4 receptors and the risk of cigarette smoking in African Americans and Caucasians. Cancer Epidemiology, Biomarkers, and Prevention, 7, 453-458.

Smith, T. F. (2010). Meta-analysis of the heterogeneity in association of DRD4 7-repeat allele and AD/HD: Stronger association with AD/HD combined type. American Journal of Medical Genetics B: Neuropsychiatry Genetics, 153B, 1189-1199.

Spangler, G., \& Grossmann, K. E. (1993). Biobehavioral organization insecurely and insecurely attached infants. Child Development, 64, 1439-1450.

Spangler, G., Schiechle, M., Ilg, U., Maier, U., \& Ackerman, C. (1994). Maternal sensitivity as an external organizer for biobehavioral regulation in infancy. Developmental Psychobiology, 27, 425-437.

Stipek, D., \& Ryan, R. (1997). Economically disadvantaged preschoolers: Ready to learn by further to go. Developmental Psychology, 33, 711-723.

Suhara, T., Yasuno, F., Sudo, Y., Yamamoto, M., Inoue, M., Okubo, Y., et al. (2001). Dopamine D2 receptors in the insular cortex and the personality trait of novelty seeking. NeuroImage, 13, 891-895.
Sunohara, G. A., Roberts, W., Malone, M., Schachar, R. J., Tannock, R., Basile, V. S., et al.. (2000). Linkage of the dopamine D4 receptor gene and attention-deficit/hyperactivity disorder. Journal of the American Academy of Child \& Adolescent Psychiatry, 39, 1537-1542.

Thompson, R. A. (1994). Emotion regulation: A theme in search of a definition. Monographs of the Society for Research in Child Development, 59(2-3, Serial No. 240), 25-52.

Thompson, R. A. (1997). Sensitivity and security: New questions to ponder. Child Development, 68, 595-597.

van den Boom, D. C. (1994). The influence of temperament and mothering on attachment and exploration: An experimental manipulation of sensitive responsiveness among lower-class mothers with irritable infants. Child Development, 65, 1457-1477.

van den Boom, D. C. (1997). Sensitivity and attachment: Next steps for developmentalists. Child Development, 68, 592-594.

Welsh, M., Parke, R. D., Widaman, K., \& O’Neil, R. (2001). Linkages between children's social and academic competence: A longitudinal analysis. Journal of School Psychology, 39, 463-482.

Wiers, R. W., Sergeant, J. A., \& Gunning, W. B. (1994). Psychological mechanisms of enhanced risk of addiction in children of alcoholics: A dual pathway? Acta Paediatrica, 404(Suppl.), 9-13.

Williams, S., \& McGee, R. (1994). Reading attainment and juvenile delinquency. Journal of Child Psychology and Psychiatry, 35, 441-459.

Wise, R. A. (2004). Dopamine, learning, and motivation. Nature Reviews Neuroscience, 5, 483-494.

Woodcock, R. W., McGrew, K., \& Mather, N. (2001). The Woodcock-Johnson Tests of Achievement (3rd ed.). Itasca, IL: Riverside.

Zhang, Y., Bertolino, A., Fazio, L., Blasi, G., Rampino, A., Romano, R. et al. (2007). Polymorphisms in human dopamine D2 receptor gene affect gene expression, splicing, and neuronal activity during working memory. Proceedings of the National Academy of Sciences, 104, 20552-20557.

Zukerman, M. (1994). Impulsive unsocialized sensation seeking: The biological foundations of a basic dimension of personality. In J. Bates \& T. Wachs (Eds.), Temperament: Individual differences at the interface of biology and behavior (pp. 219-255). Washington, DC: American Psychological Association. 